\title{
Impact of silver nanoparticles (AgNP) on soil microbial community depending on functionalization, concentration, exposure time, and soil texture
}

\author{
Anna-Lena Grün ${ }^{1,6}$, Werner Manz ${ }^{1}$, Yvonne Lydia Kohl ${ }^{2}$, Florian Meier ${ }^{3}$, Susanne Straskraba ${ }^{4}$, Carsten Jost ${ }^{5}$,
} Roland Drexel ${ }^{3}$ and Christoph Emmerling ${ }^{6^{*}}$ (D)

\begin{abstract}
Background: Increasing exposure to engineered inorganic nanoparticles takes actually place in both terrestric and aquatic ecosystems worldwide. Although we already know harmful effects of AgNP on the soil bacterial community, information about the impact of the factors functionalization, concentration, exposure time, and soil texture on the AgNP effect expression are still rare. Hence, in this study, three soils of different grain size were exposed for up to 90 days to bare and functionalized AgNP in concentrations ranging from 0.01 to $1.00 \mathrm{mg} / \mathrm{kg}$ soil dry weight. Effects on soil microbial community were quantified by various biological parameters, including $16 \mathrm{~S}$ rRNA gene, photometric, and fluorescence analyses.
\end{abstract}

Results: Multivariate data analysis revealed significant effects of AgNP exposure for all factors and factor combinations investigated. Analysis of individual factors (silver species, concentration, exposure time, soil texture) in the unifactorial ANOVA explained the largest part of the variance compared to the error variance. In depth analysis of factor combinations revealed even better explanation of variance. For the biological parameters assessed in this study, the matching of soil texture and silver species, and the matching of soil texture and exposure time were the two most relevant factor combinations. The factor AgNP concentration contributed to a lower extent to the effect expression compared to silver species, exposure time and physico-chemical composition of soil.

Conclusions: The factors functionalization, concentration, exposure time, and soil texture significantly impacted the effect expression of AgNP on the soil microbial community. Especially long-term exposure scenarios are strongly needed for the reliable environmental impact assessment of AgNP exposure in various soil types.

Keywords: Silver nanoparticles, Soil, Soil texture, Exposure time, Functionalization, Soil microbial community, LAP, Enzymes, Functional diversity

\footnotetext{
*Correspondence: emmerling@uni-trier.de

${ }^{6}$ Department of Soil Science, Faculty of Regional and Environmental

Science, University of Trier, Campus II, 54286 Trier, Germany

Full list of author information is available at the end of the article
}

\section{Springer Open}

C The Author(s) 2019. This article is distributed under the terms of the Creative Commons Attribution 4.0 International License (http://creativecommons.org/licenses/by/4.0/), which permits unrestricted use, distribution, and reproduction in any medium, provided you give appropriate credit to the original author(s) and the source, provide a link to the Creative Commons license, and indicate if changes were made. 


\section{Background}

The production volume and the application fields of silver nanoparticles (AgNP) increased continuously in the last decade given by their unique properties such as high surface-to-volume ratio, high chemical reactivity, and specific optical properties [1-3]. Apart from the initial medical utilization, AgNP are actually used in households, industry and agriculture such as for water purification, plant growth promotion and textiles cleaning [4, 5]. In consequence, their emission into the environment during all stages of the life cycle, including production, product use, disposal and weathering is unavoidable [6]. The exact extent of the release is unknown due to missing reliable and robust analytical methods for detecting trace concentrations of AgNP in complex matrices [7]. Thus, several scientists modeled the fate and concentrations of AgNP in the environment and named the soil compartment as one of the main sink of AgNP released into the environment [2, 6, 8-14]. For Europe, an annual AgNP increase of $0.6 \mathrm{t}$ and $2.09 \mathrm{t}$ was calculated for soils and sediments, respectively [8].

Today, information about the impact of AgNP on the soil microbiome are still rare, although microbial communities are important and sensitive targets for determining the environmental hazards of AgNP [15]. Recently, we registered significant negative effects on soil microbial biomass $(-38.0 \%)$, bacterial ammonia oxidizers $(-17.0 \%)$, and the beta-Proteobacteria population $(-14.2 \%)$ after 1 -year exposure to $0.01 \mathrm{mg} \mathrm{AgNP} / \mathrm{kg}$ in a loamy soil, while Acidobacteria (44.0\%), Actinobacteria (21.1\%) and Bacteroidetes (14.6\%) were significantly stimulated [16, 17]. Therefore, a detrimental disturbance on soil ecosystem functions, such as nitrification, organic carbon transformation and chitin degradation could be assumed.

Numerous studies documented the differing physico-chemical and concomitant toxicological behavior of AgNP in dependence of the soil type. As a function of $\mathrm{pH}$, ionic strength, temperature, amount of dissolved ions and of natural organic matter, oxygen concentration, grain size distribution and others [18-21], AgNP could undergo various physico-chemical transformations such as reduction, oxidation, aggregation, dissolution, complexation and further secondary reactions [21-24]. Consequently, these transformations in turn affect the toxicity mechanism of AgNP as well as their bioavailability. For example, in comparative studies with different soil types, Schlich and Hund-Rinke [19] as well as Rahmatpour et al. [25] showed that AgNP caused lower toxicity in soils with higher clay content due to the AgNP immobilization by heteroaggregation with clay particles $[19,23,25]$.

In addition, the AgNP species itself may significantly impact on its environmental behavior. Their size, shape, surface-coating agent, charge and stability are only a few of the properties by which AgNP can differ [1]. Today, extensive functionalization strategies are available to modify the surface chemistry of a variety of engineered nanoparticles (NP) [26]. Those coatings are used to stabilize NP against aggregation when stable suspensions are required for product functionality or for improved delivery of the product. The coating may also provide other functionalities, such as biocompatibility or targeting of specific cells in biomedical applications [27]. For example, AgNP can be coated by citrate or polyvinylpyrrolidine to increase their stability [28], modified with ATP to act as a selective antibiotic [29] or equipped with $\mathrm{COOH}-$ and $\mathrm{NH}_{2}$-groups to affect their surface charge in terms of their function in imaging and drug delivery [30]. Once released into the environment, the surface functionalization of AgNP significantly determines its physico-chemical fate, its bioavailability and its toxicity [22, 26]. Exemplary, Wu et al. [31] observed in a nanocosm experiment that polyethylene glycol AgNP had the highest overall toxicity, followed by silica AgNP, and lastly aminated silica-coated AgNP due to there different dissolution rates und thus stability.

Further to the soil type and the AgNP functionalization, several studies documented a significant impact of the exposure time on the toxicity of AgNP in soils [16, $32-34]$. By a statistically significant regression and correlation analysis between silver toxicity and exposure time we recently confirmed loamy soils as a sink for silver nanoparticles and their concomitant silver ions due to ageing processes of the silver species and their slow return to the biological soil system [17].

Considering the predicted increase of AgNP into the soil environment, the known toxicity of AgNP to the soil microbial community as well as the variable fate of AgNP in the soil compartment, the aim of this study was to give a more holistic view of the impact of AgNP exposure on the soil microbial community in dependence of the factors AgNP functionalization, AgNP concentration, exposure time, and soil texture. The study was conducted with a long-term incubation period of 90 days using three soil textures (loam, clay, sand) and two different charged AgNP at concentrations in a range of $0.01-1.00 \mathrm{mg}$ AgNP $/ \mathrm{kg}$ soil. We quantified the effects on several biological parameter: the microbial biomass, the abundance of bacteria, the enzymatic activity as well as marker genes for selected processes of the inorganic nitrogen cycle and for selected higher bacterial taxa. Furthermore, we used $\mathrm{AgNO}_{3}$ as control to determine the effect of $\mathrm{Ag}^{+}$ions on the AgNP results. Based on our preceding observation that the nitrate content of $36.5 \%$ in the $\mathrm{AgNO}_{3}$ compound might also have effects on the microbial community [16], we used $\mathrm{NO}_{3}$ as a further control. This experiment was 
restricted to the loamy soil. Here, we analysed the impact charged and uncharged AgNP as well as the effects of $\mathrm{AgNO}_{3}$ and $\mathrm{NO}_{3}$ on the microbial community.

\section{Materials and methods}

\section{Silver nanoparticles and controls}

Two differently functionalized AgNP were used, Ag10$\mathrm{COOH}$ functionalized with carboxy groups and Ag10$\mathrm{NH}_{2}$ functionalized with amino groups. The AgNP were synthesized by a ligand exchange starting from hydrophobic silver particles (Ag-HPB) and the addition of toluene and mercaptopropionic acid or cysteamine hydrochloride in $\mathrm{MeOH}$ to receive the final $\mathrm{Ag} 10-\mathrm{COOH}$ or Ag10- $\mathrm{NH}_{2}$ colloidal solutions. The concentration of the stock solutions were $180 \mathrm{mg} / \mathrm{L}$ for $\mathrm{Ag} 10-\mathrm{COOH}$ and $21 \mathrm{mg} / \mathrm{L}$ for Ag10- $\mathrm{NH}_{2}$. Size, shape and nanoparticle surface charge ( $\zeta$-potential) of AgNP were analysed by transmission electron microscopy (Philips CM 12, Netherlands), dynamic light scattering (DLS, Zetasizer Nano S, Malvern Instruments Ltd., UK), asymmetrical flow field-flow fractionation (AF4, AF2000 MT, Postnova Analytics GmbH, Germany) and Laser-Doppler-microelectrophoresis (Malvern Zetasizer Nano-ZS, Malvern Instruments Ltd., UK).

Methods of synthesis and particle characterization can be found in detail in Additional file 1 .

Additionally to the analysis of the stock solution, $\zeta$-potential and hydrodynamic diameter of the AgNP were determined at different $\mathrm{pH}$ values $(\mathrm{pH} 4, \mathrm{pH} 7.4$ and $\mathrm{pH} 10$ ). Prior to the measurements the stock solution was diluted in pure water (Millipore) with the $\mathrm{pH}$-values $4,7.4$ or 10 to a concentration of $10 \mu \mathrm{g} / \mathrm{mL}$, vortexed for $10 \mathrm{~s}$, incubated for $1 \mathrm{~h}$ or $24 \mathrm{~h}$ under permanent rotation $\left(100 \mathrm{rpm}\right.$ at $\left.37^{\circ} \mathrm{C}\right)$ and vortexed for $30 \mathrm{~s}$ prior to analysis via Zetasizer Nano-ZS.

Silver nitrate $\left(\mathrm{AgNO}_{3}\right)$ was used as a positive control. Silver concentrations in the $\mathrm{AgNO}_{3}$ controls were the same as those in the AgNP treatments. As a further control, $\mathrm{NO}_{3}{ }^{-}$was used in form of $\mathrm{KNO}_{3}$. The nitrate concentration in the $\mathrm{KNO}_{3}$ controls were the same as those in the $\mathrm{AgNO}_{3}$ treatments.

\section{Test soils}

Three soil textures were selected: a silty sand, a loamy clay and a silty loam. Approximately $20 \mathrm{~kg}$ of each soil was sampled from the A-horizon $(0-30 \mathrm{~cm}$ depth) in spring 2015 next to Trier, Germany. Land-use was forest for the sandy soil and arable field for the clayey and the loamy soil. The soil had a clay content of $0-5 \%$ for the sandy, $45-65 \%$ for the clayey, and $25-35 \%$ for the loamy soil, respectively. After sampling, the soils were thoroughly sieved to $<2 \mathrm{~mm}$ and stored at $6{ }^{\circ} \mathrm{C}$ until further use. Characteristic soil parameters are listed in Table 1.
Table 1 Characterization of the test soils

\begin{tabular}{|c|c|c|c|}
\hline \multirow{2}{*}{$\begin{array}{l}\text { Parameter } \\
\text { Location site }\end{array}$} & \multicolumn{3}{|l|}{ Properties } \\
\hline & Wolsfeld & Trierweiler & Helenenberg \\
\hline Soil type (WRB) & Podzol & Stagno-Cambisol & Stagno-Luvisol \\
\hline Soil texture & Silty sand & Loamy clay & Silty loam \\
\hline Clay content (\%) & $0.0-5.0$ & $45.0-65.0$ & $25.0-35.0$ \\
\hline Sand content (\%) & 70.0-90.0 & $5.0-40.0$ & $25.0-45.0$ \\
\hline $\mathrm{pH}\left(0.01 \mathrm{~mol} / \mathrm{L} \mathrm{CaC}_{12}\right)$ & 3.2 & 7.4 & 7.2 \\
\hline TOC (\%) & 1.8 & 5.2 & 4.7 \\
\hline TN (\%) & 0.1 & 0.3 & 0.2 \\
\hline $\begin{array}{l}\text { CEC (mmol/kg dry } \\
\text { matter) }\end{array}$ & 9.1 & 199.4 & 193.3 \\
\hline $\begin{array}{l}\mathrm{Ca}^{2+}(\mathrm{mmol} / \mathrm{kg} \text { dry } \\
\text { matter })\end{array}$ & 4.7 & 136.0 & 123.5 \\
\hline $\begin{array}{l}\mathrm{Mg}^{2+}(\mathrm{mmol} / \mathrm{kg} \mathrm{dry} \\
\text { matter })\end{array}$ & 2.4 & 47.6 & 55.8 \\
\hline $\mathrm{K}^{+}$(mmol/kg dry matter) & 0.4 & 14.5 & 12.8 \\
\hline $\begin{array}{l}\mathrm{Na}^{+} \text {(mmol/kg dry } \\
\text { matter) }\end{array}$ & 0.3 & 1.1 & 0.9 \\
\hline $\begin{array}{l}\mathrm{Fe}^{2+}(\mathrm{mmol} / \mathrm{kg} \mathrm{dry} \\
\text { matter })\end{array}$ & 1.1 & 0.0 & 0.0 \\
\hline $\begin{array}{l}\mathrm{Mn}^{2+}(\mathrm{mmol} / \mathrm{kg} \text { dry } \\
\text { matter })\end{array}$ & 0.2 & 0.3 & 0.4 \\
\hline
\end{tabular}

$W R B$ world reference base for soil resources

\section{Experimental design}

Before starting the experiment, the soil was moistened and incubated at $18{ }^{\circ} \mathrm{C}$ for 7 days. The application of the test materials was performed in petri dishes, each filled with soil equivalent to $25 \mathrm{~g}$ dry weight.

AgNP test solutions were prepared immediately before use: AgNP stock solutions were sonicated at $42 \mathrm{~W} / \mathrm{L}$ for $15 \mathrm{~min}$ and gradually diluted with UPW. Then, $1 \mathrm{~mL}$ of the agent species Ag10-COOH, $\mathrm{Ag} 10-\mathrm{NH}_{2}, \mathrm{AgNO}_{3}$ or $\mathrm{KNO}_{3}$ solutions, at different concentrations, was added in small drops onto the soil surface to obtain final concentrations of $0.01,0.10$ and $1.00 \mathrm{mg} / \mathrm{kg}$ dry weight. Negative controls only received an application of UPW. Soil water content after the addition of the test solutions were average $22.0 \%$ (sand), $19.4 \%$ (clay) and $18.5 \%$ (loam), which was equivalent to $42.6 \%, 41.4 \%$, and $37.4 \%$ $\mathrm{WHC}_{\max }$, respectively. For each soil texture, agent species, concentration, and day, separate samples in different soil dishes were prepared as 4 replicates (e.g. $4 \times 0.01 \mathrm{mg}$ $\mathrm{Ag} 10-\mathrm{COOH} \mathrm{kg}{ }^{-1}$ sand for day 1). Subsequently, soils were extensively mixed by stirring with a spoon, and then they were transferred to plastic containers (Centrifuge Tubes, $50 \mathrm{~mL}$, VWR, Darmstadt, Germany) and sealed by Parafilm ${ }^{\circledR}$. They were incubated at $15.1\left( \pm 1.8^{\circ} \mathrm{C}\right)$ in the dark for $1,14,28$, and 90 days. Water evaporation was determined gravimetrically and then compensated with the addition of UPW. Samples were finally stored at $-20{ }^{\circ} \mathrm{C}$. For analyses, samples were defrosted by incubation overnight at $6{ }^{\circ} \mathrm{C}$. Each replicate was analysed on the 
effect expressions of the target variables leucine aminopeptidase activity, microbial biomass as well as of functional and taxonomic genes.

Furthermore, results of our previous studies [16, 17] of the effect assessment of AgPure, with an average size of $20 \mathrm{~nm}$ and polyacrylate stabilization, were used to calculate the impact of the five agent species AgPure, Ag10$\mathrm{COOH}, \mathrm{Ag} 10-\mathrm{NH}_{2}, \mathrm{AgNO}_{3}$, and $\mathrm{KNO}_{3}$ at concentrations of $0.01 ; 0.1$; and $1.0 \mathrm{mg} \mathrm{Ag} / \mathrm{kg}$ soil after exposure of 1,14 , 28 , and 90 days in the silty loam soil on the same target variables.

\section{Analysis of biological parameters Leucine aminopeptidase activity}

Leucine aminopeptidase (EC 3.4.1.1; LAP) was investigated according to Marx et al. [35], with modifications [36]. Briefly, $1 \mathrm{~mol} / \mathrm{L}$ L-leucin-7-AMC was used as substrate for LAP, and 7-amino-4-methylcoumarin [37] was used as a standard. Incubation of the soil slurry with the substrate was performed at $30^{\circ} \mathrm{C}$. Measurements of fluorescence were performed after 0 and $2 \mathrm{~h}$ using a Victor Multilabel Plate Reader (Perkin Elmer, Germany; excitation wavelength: $355 \mathrm{~nm}$, emission wavelength: $460 \mathrm{~nm}$ ). LAP activity was calculated as substrate turnover per $\mathrm{g}$ dry soil $h$.

The potential contribution of AgNP to the total fluorescence signal was measured for each AgNP concentration. Then, AgNP was added to autoclaved soil, and the same procedure was conducted. The resulting fluorescence signal was compared to the fluorescence intensity of the pure autoclaved soil. At this, the used AgNP did not exhibit autofluorescence (data not shown).

\section{DNA extraction and microbial biomass measurements}

DNA extraction and purification were performed using the Genomic DNA from soil kit (Macherey-Nagel, Düren, Germany) according to the manufacturer's instructions and stored at $-20{ }^{\circ} \mathrm{C}$. For the measurement of microbial biomass, $10 \mu \mathrm{L}$ of DNA was transferred into the well of a 96-well microplate and shaken for $5 \mathrm{~s}$ before absorbance was measured at $260 \mathrm{~nm}$ [38] using Victor Multilabel Plate Reader (Perkin Elmer, Germany).

\section{Quantitative detection of functional and taxonomic genes}

$16 S$ rRNA genes were used as a proxy to quantify the abundance of bacteria, as described by Bach et al. [39]. The abundance of bacteria harboring the nifH gene was used as a marker for the potential to fix nitrogen and measured according to Rösch et al. [40]. To analyze the effects of the different silver materials on the ammoniaoxidizing bacteria, the amo $A$ primer system described by Rotthauwe et al. [41] was used. To quantify the abundance of taxon-specific 16S rRNA gene copy numbers,
qPCR assays for Acidobacteria [42, 43], Actinobacteria [43, 44], alpha-Proteobacteria [45], Bacteroidetes [43, 46], and beta-Proteobacteria [47, 48] were performed. Detailed descriptions of the used assays are given by Grün and Emmerling [17] and Grün et al. [16].

All qPCR reactions were conducted on a thermal cycler equipped with an optical module (Analytik Jena, Jena, Germany). All samples were run in triplicate wells. Single qPCR reactions were prepared in a total volume of $20 \mu \mathrm{L}$. The InnuMix SYBR-Green qPCR Master-Mix was purchased from Analytik Jena (Jena, Germany). Primer concentrations were $10 \mathrm{pmol} / \mu \mathrm{L}$, and amplification specificity was assessed by melting curve analysis and gel electrophoresis on a $1.5 \%$ agarose gel after qPCR. Standard curves were based on cloned PCR products from the respective genes [43].

\section{Statistical analyses}

All data were processed using IBM SPSS Statistics for Windows, Version 23.0 (IBM Corp., Armonk, USA). The obtained biological values of qPCR (copy gene number per kg dry soil), leucine aminopeptidase activity (substrate turnover per g dry soil h) and measurement of microbial biomass (ng DNA per g dry soil) of negative controls $(0.00 \mathrm{mg} \mathrm{Ag} / \mathrm{kg})$ of the 4 sample replicates were averaged for each biological parameter and day. Subsequent, the relative variation of each silver treated sample of one concentration and one sampling date were calculated as follow:

Relative variation (\%)

$$
\begin{aligned}
& \text { averaged biological value of untreated samples } \\
& \times 100
\end{aligned}
$$

In the following, the relative variation was set as target variables. Exposure time (1, 14, 28, 90 days), concentration $(0.01 ; 0.1 ; 1.0 \mathrm{mg} \mathrm{Ag} / \mathrm{kg}$ soil), soil texture (loam, sand, clay) and silver species (Ag10-COOH, $\mathrm{Ag} 10-\mathrm{NH}_{2}$, $\mathrm{AgNO}_{3}$ ) were set as factors with different factor levels (e.g. Ag10-COOH, Ag10- $\mathrm{NH}_{2}, \mathrm{AgNO}_{3}$ ).

For the effect assessment of a factor level on the target variable, the mean of a target variable (e.g. leucine aminopeptidase) at a distinct factor level (e.g. Ag10-COOH) was calculated. Within a factor, the target variable was also pre-evaluated for a normal distribution by the Shapiro-Wilk test and variance homogeneity by the Levene test.

To test the influence of the four factors as well as the influence of the factor combination on the target variable, multi-factorial ANOVA was performed. Here, tests of between-subject effects provided information about 
significant relationships. By means of the Bonferroni post hoc test the significance of group mean differences within a factor were calculated.

Finally, a multivariate analysis of variance was performed to simultaneously mitigate the influence of the four factors on the 10 dependent target variables. The factors were set as independent variables, whereas the relative variations of the biological parameters were set as dependent variables. The test statistic was computed by Pillai's trace.

\section{Results}

\section{Characterization of the AgNP suspensions prior to application into soils}

Characteristics of the Ag10-COOH stock solution in water were as follows: hydrodynamic diameter (DLS, z-average): $85.3 \pm 2.9 \mathrm{~nm}$; polydispersity index (PDI) $(D L S)=0.234 \pm 0.031 ; \zeta$-potential: $-41.4 \pm 1.1 \mathrm{mV}$ (in UPW). AF4-UV-DLS measurement revealed an average hydrodynamic diameter of $18.1 \pm 0.5 \mathrm{~nm}$ at the UV peak maximum. Over the main UV peak the hydrodynamic diameter ranged from $18 \mathrm{~nm}$ to around $28 \mathrm{~nm}$. Larger particle sizes with a hydrodynamic diameter up to around $118 \mathrm{~nm}$ were detected as well but larger particle fractions were low in concentration based on the corresponding UV signal (Fig. 1a).

Characteristics of the Ag10- $\mathrm{NH}_{2}$ stock solution in water were as follows: hydrodynamic diameter (DLS, $\mathrm{z}$-average): $62.1 \pm 3.1 \mathrm{~nm}$; polydispersity index (PDI) $(\mathrm{DLS})=0.379 \pm 0.072 ; \zeta$-potential: $+39.2 \pm 0.2 \mathrm{mV}$ (in UPW). Average hydrodynamic diameter at the UV peak maximum obtained from AF4-UV-DLS measurement:
$82.3 \mathrm{~nm} \pm 3.1 \mathrm{~nm}$ with a size distribution from around $8 \mathrm{~nm}$ to $142 \mathrm{~nm}$ (Fig. $1 \mathrm{~b}$ ).

The analysis of the $\zeta$-potential and hydrodynamic diameter of the AgNP under different $\mathrm{pH}$ values resulted in $\mathrm{pH}$-dependent characteristics of the NP (Fig. 2). The hydrodynamic diameter was $197 \pm 13.9 \mathrm{~nm}$ after $1 \mathrm{~h}$ incubation in a $\mathrm{pH} 4$ solution and $169 \pm 9.2 \mathrm{~nm}$ in a $\mathrm{pH} 7.4$ solution for Ag10$\mathrm{NH}_{2}$ (Fig. 2a). There was no difference in the results after $1 \mathrm{~h}$ and $24 \mathrm{~h}$ incubation. Under alkaline conditions $(\mathrm{pH} \mathrm{10)}$, the hydrodynamic diameter increased to $601 \pm 85 \mathrm{~nm}(1 \mathrm{~h})$ or $1911 \pm 475 \mathrm{~nm}(24 \mathrm{~h})$. Starting from the stock solution, with a positive surface charge of $+39.2 \pm 0.2 \mathrm{mV}$, the surface charge decreased with increasing $\mathrm{pH}$ value (Fig. 2b). After $1 \mathrm{~h}$ incubation of Ag10- $\mathrm{NH}_{2}$ in aqueous $\mathrm{pH} 4$ solution, the $\zeta$-potential was $+36.9 \pm 2.5 \mathrm{mV}$ and decreased to $-7.4 \pm 1.5 \mathrm{mV}$ after $1 \mathrm{~h}$ incubation in a matrix with $\mathrm{pH} 10$. But there was no significant difference between the results after $1 \mathrm{~h}$ and $24 \mathrm{~h}$ incubation.

Ag10-COOH behaved contrarily. After $1 \mathrm{~h}$ incubation, the hydrodynamic diameter of $\mathrm{Ag}-\mathrm{COOH}$ at $\mathrm{pH} 4,7.4$ and 10 was comparable. After $24 \mathrm{~h}$ the size significantly increased at $\mathrm{pH} 4$, but not at $\mathrm{pH} 7.4$ and 10 (Fig. 2c). The $\zeta$-potential mainly did not vary significantly between the different $\mathrm{pH}$ values. After incubation for $24 \mathrm{~h}$ at $\mathrm{pH} 10$ there was a significant increase in the surface charge to negative $(-54.1 \pm 2.9 \mathrm{mV})$ (Fig. $2 \mathrm{~d}$ ).

Transmission electron microscopy revealed an averaged diameter of $5.7 \pm 2.3 \mathrm{~nm}$ for Ag10-COOH (Fig. 3a). Their distribution among the grid was not homogeneous but rather arranged in clusters. Between the dark grey and black single particles there was a lighter colored layer with very small objects in it. This could be a residue from
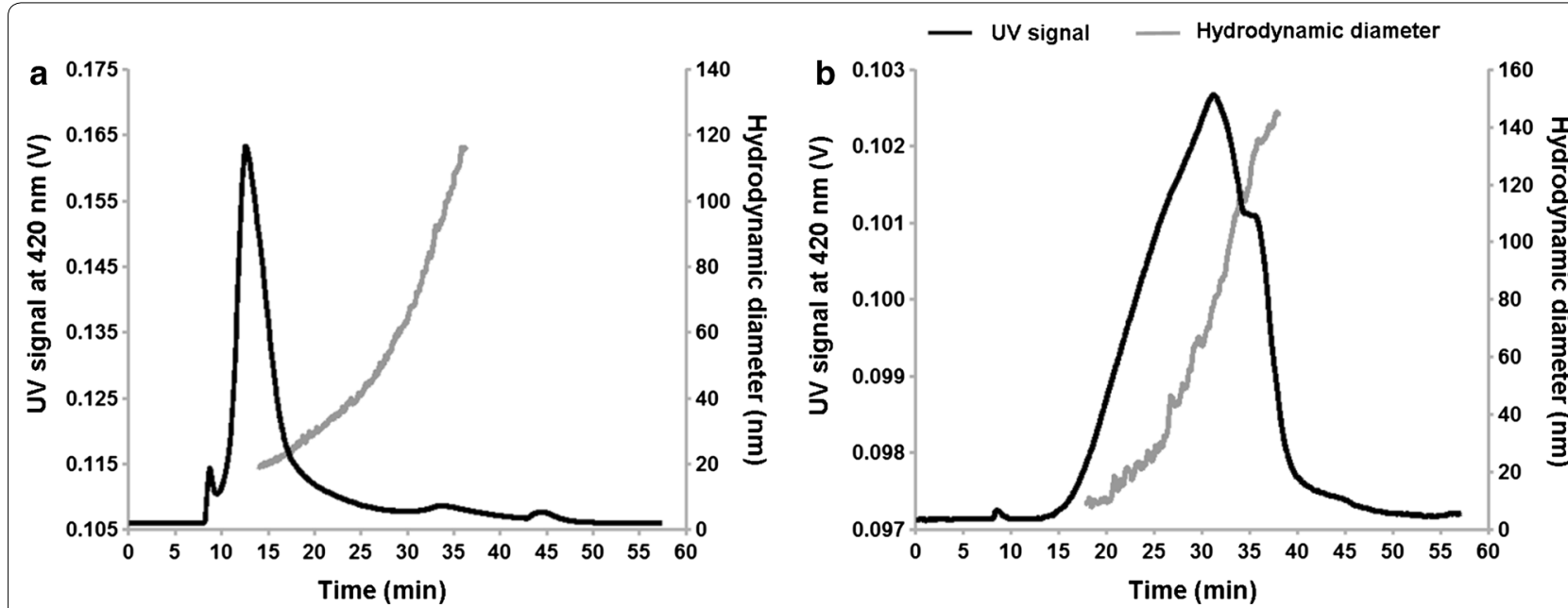

Fig. 1 AF4-UV-DLS measurements of $\mathrm{Ag} 10-\mathrm{COOH}$ (a) and $\mathrm{Ag} 10-\mathrm{NH}_{2}$ (b) 


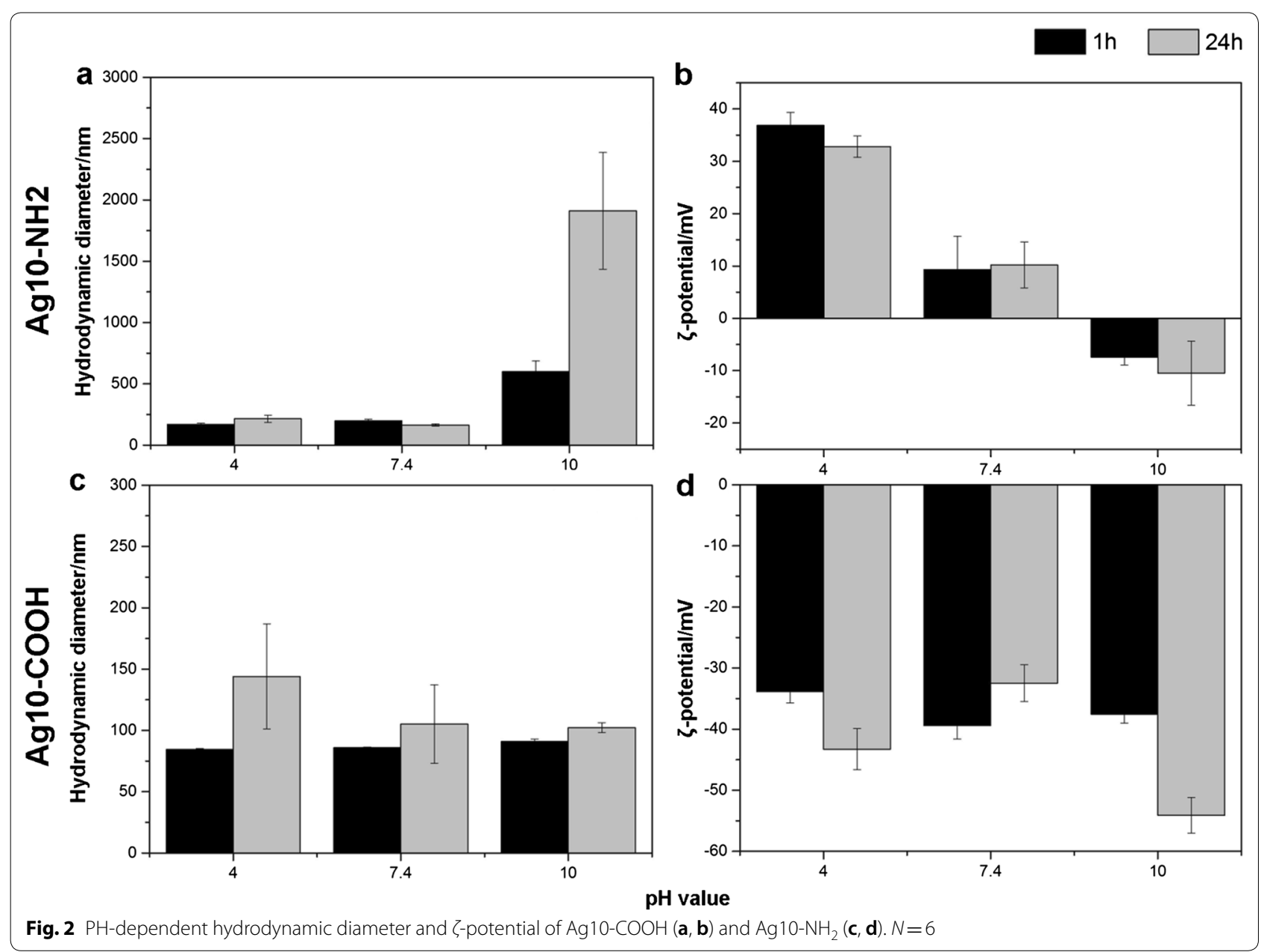

Fig. $2 \mathrm{PH}$-dependent hydrodynamic diameter and $\zeta$-potential of $\mathrm{Ag} 10-\mathrm{COOH}(\mathbf{a}, \mathbf{b})$ and $\mathrm{Ag} 10-\mathrm{NH}_{2}(\mathbf{c}, \mathbf{d}) . \mathrm{N}=6$
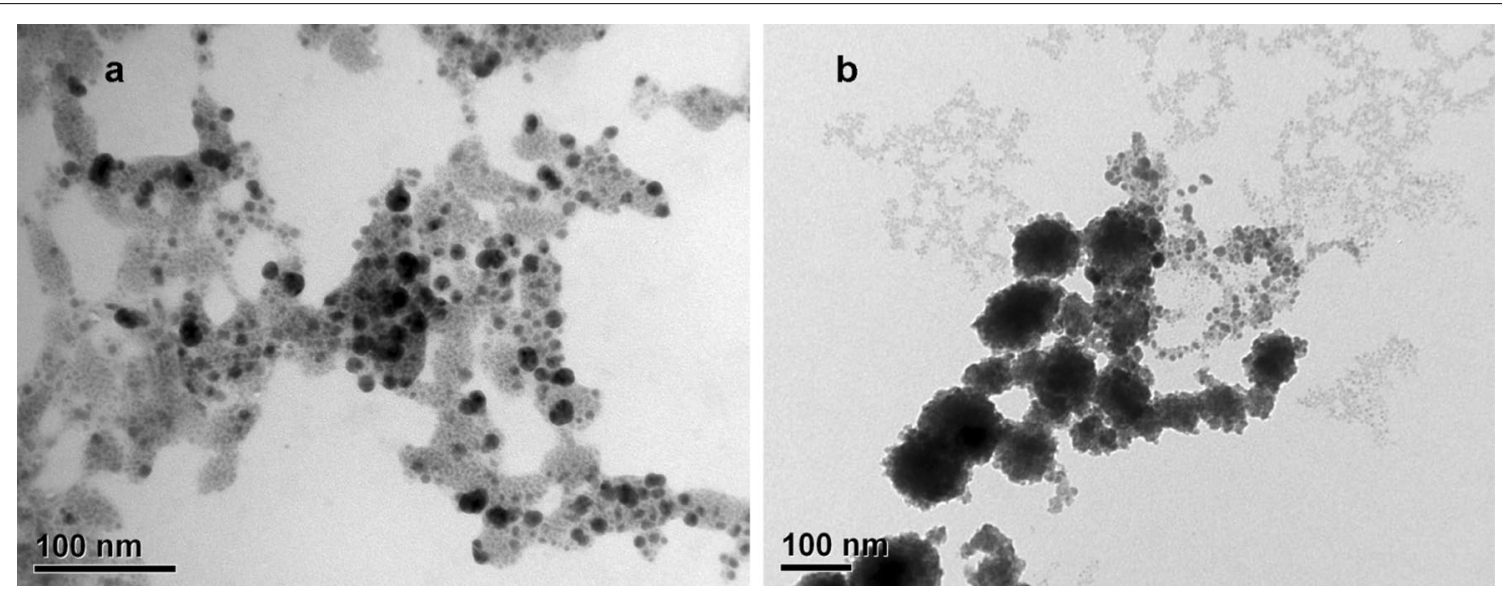

Fig. 3 Transmission electron microscope (TEM) image of $\mathrm{Ag} 10-\mathrm{COOH}(\mathbf{a})$ and $\mathrm{Ag} 10-\mathrm{NH}_{2}$ (b) in water

the production process. The single particles were shaped roundish to oval. The Ag10- $\mathrm{NH}_{2}-\mathrm{NP}$ showed an average diameter of $6.2 \pm 3.4 \mathrm{~nm}$ (Fig. 3b). They were not distributed homogeneously among the grid and agglomerate to secondary particles with a diameter of over $100 \mathrm{~nm}$. Beside these particles there were areas with single nanoparticles which had a roundish to oval shape and a plain surface. 
Impact of silver species, exposure time, concentration, soil texture and their combinations on biological parameters

Results of multi-factorial ANOVA revealed significant main effects of the factors silver species, concentration, exposure time and soil texture on the relative variation of the bacterial phyla Actinobacteria, Acidobacteria, alphaProteobacteria, Bacteroidetes and beta-Proteobacteria (Table 2). Comparable significant results were observed for the leucine aminopeptidase (LAP) activity, the microbial biomass, the abundance of all bacteria (16S rRNA), as well as for the ammonia-oxidizing bacteria (amoA) (Table 2). In case of the relative variation of the free-living nitrogen-fixing bacteria $(n i f H)$ only the factors and factor levels of exposure time and soil texture caused significant effects (Table 2). Silver species and concentration provoked no significant impacts on nifH (Table 2). The interaction effects of the factor combinations were predominantly significant for all variables (Table 2 ).

The considered main factors as well as their interactions could explain at least $81.5 \%\left(R^{2}=0.815\right)$ of the variance of the respective target variables; in the case of beta-Proteobacteria even $93.9 \%\left(R^{2}=0.939\right.$, Table 2$)$.

Results of multivariate analysis revealed significant main effects for all factors and factor combinations (Table 2). MANOVA scored the factor combination soil texture $\times$ silver species as the strongest option $(F=53.2)$, followed by the combination of soil texture $\times$ exposure time $(F=46.8)$ (Table 2). Nevertheless, also the main factors silver species $(F=44.2)$, exposure time $(F=43.9)$ and soil texture $(F=46.5)$ could broadly explain the variance compared to the error variance itself (Table 2). The main factor concentration could elucidate the least variance $(F=12.7)$ (Table 2).

In Fig. 4 the influence of the highest scored factor combinations silver species $\times$ soil texture and exposure time $\times$ soil texture on the relative variation of the biological parameters are highlighted.

The silver species Ag10-COOH caused similar effects in the loamy (101.2\%) and the clayey (99.4\%) soil, whereas $\mathrm{Ag} 10-\mathrm{COOH}$ diminished the relative variation of the biological parameters significantly in pairwise comparison to the sandy soil (93.3\%; $p=0.000)$ (Fig. 4a). The effects of Ag10- $\mathrm{NH}_{2}$ were also very similar between the loamy (95.8\%) and the clayey soil (98.0\%), causing no significant differences. The pairwise comparison of clayey and sandy (94.0\%) soil exhibited significant differences on the biological parameters $(p=0.003)$, while between sandy and loamy soil no differences could be detected. $\mathrm{AgNO}_{3}$ control slightly stimulated the entirety of the relative variation of the biological parameters in the loamy (101.2\%) and sandy (103.6\%) soil. In contrast $\mathrm{AgNO}_{3}$ caused a significant decrease of the relative variation $(89.1 \%, p=0.000)$ in the clayey soil. The order of increasing toxicity were for the loam Ag10$\mathrm{COOH}=\mathrm{AgNO}_{3}<\mathrm{Ag} 10-\mathrm{NH}_{2}$, for the clayey soil Ag10$\mathrm{COOH}=\mathrm{Ag} 10-\mathrm{NH}_{2}<\mathrm{AgNO}_{3}$ and for the sandy soil $\mathrm{AgNO}_{3}<\mathrm{Ag} 10-\mathrm{NH}_{2}=\mathrm{Ag} 10-\mathrm{COOH}$.

As shown in Fig. 4b, a 1-day exposure to the silver species at different concentration led to a clear distinction between the effect in the sandy soil relative to the clayey $(p=0.029)$ as well as the loamy soil $(p=0.001)$. Here, the sandy soil exhibited the lowest toxicity. During the mid-term exposure of 14 and 28 days, this trend reversed and the sandy soil proved to be more toxic in response to treatment with silver compared to the loamy soil $(p \leq 0.05)$. However, after 90 days of silver exposure, an increase in the relative deviation of the biological variables from their untreated controls from the sandy to the clayey to the loamy soil could be observed (Fig. 4b). At this, there were only significant pairwise differences between the sandy and the loamy soil $(p=0.000)$, as well as between the sandy and the clayey soil $(p=0.001)$.

\section{Impact of agent species, exposure time, concentration and their combinations on biological parameters in a loamy soil}

Results of multi-factorial ANOVA revealed significant main effects of the factors agent species and exposure time on the relative variation of all biological target variables in the loamy soil (Table 3). In the case of the main factor concentration, only LAP activity, microbial biomass, amoA, Actinobacteria, Acidobacteria, and betaProteobacteria were significantly affected by the factor levels. The main factor exposure time was able to explain the largest part of the variance compared to the error variance of all target variable except for Acidobacteria and beta-Proteobacteria (Table 3). For these, the highest $F$-values were created by the main factor agent species. The main factor concentration could elucidate the least variance.

The majority of significant mean differences in a factor were found for Ag10-COOH and AgPure, 0.01 and $0.10 \mathrm{mg} / \mathrm{kg}$ silver as well as 0.01 and $1.00 \mathrm{mg} / \mathrm{kg}$ silver, and 1 day and 14 days, 14 days and 90 days as well as 28 days and 90 days (Table 3 ). No factor combination achieved higher variance explanations than the single main factors (Table 3).

Based on the results of the MANOVA, all factors and factor combinations revealed significant main effects (Table 3). The main factor exposure time clarified the largest amount of variance by a $F$-value of 56.0 , followed by the main factor agent species $(F=18.8)$ (Table 3$)$. The main factor concentration could elucidate the least variance again. The means of the highest scored individual factor levels of exposure time and agent species are visualized in Fig. 5. 


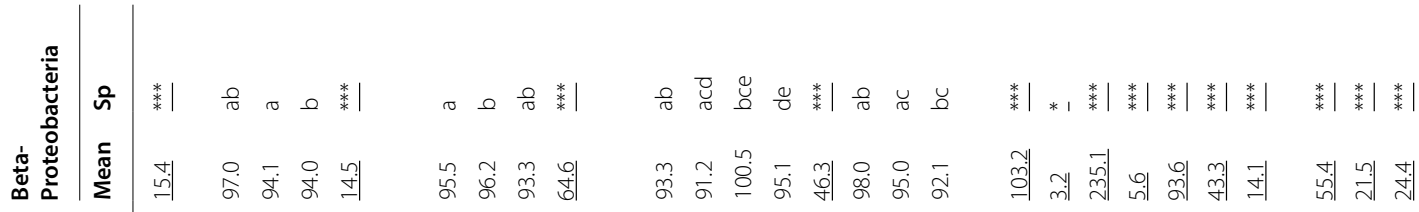

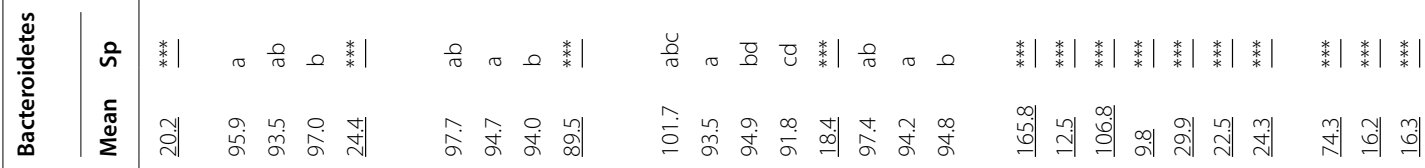

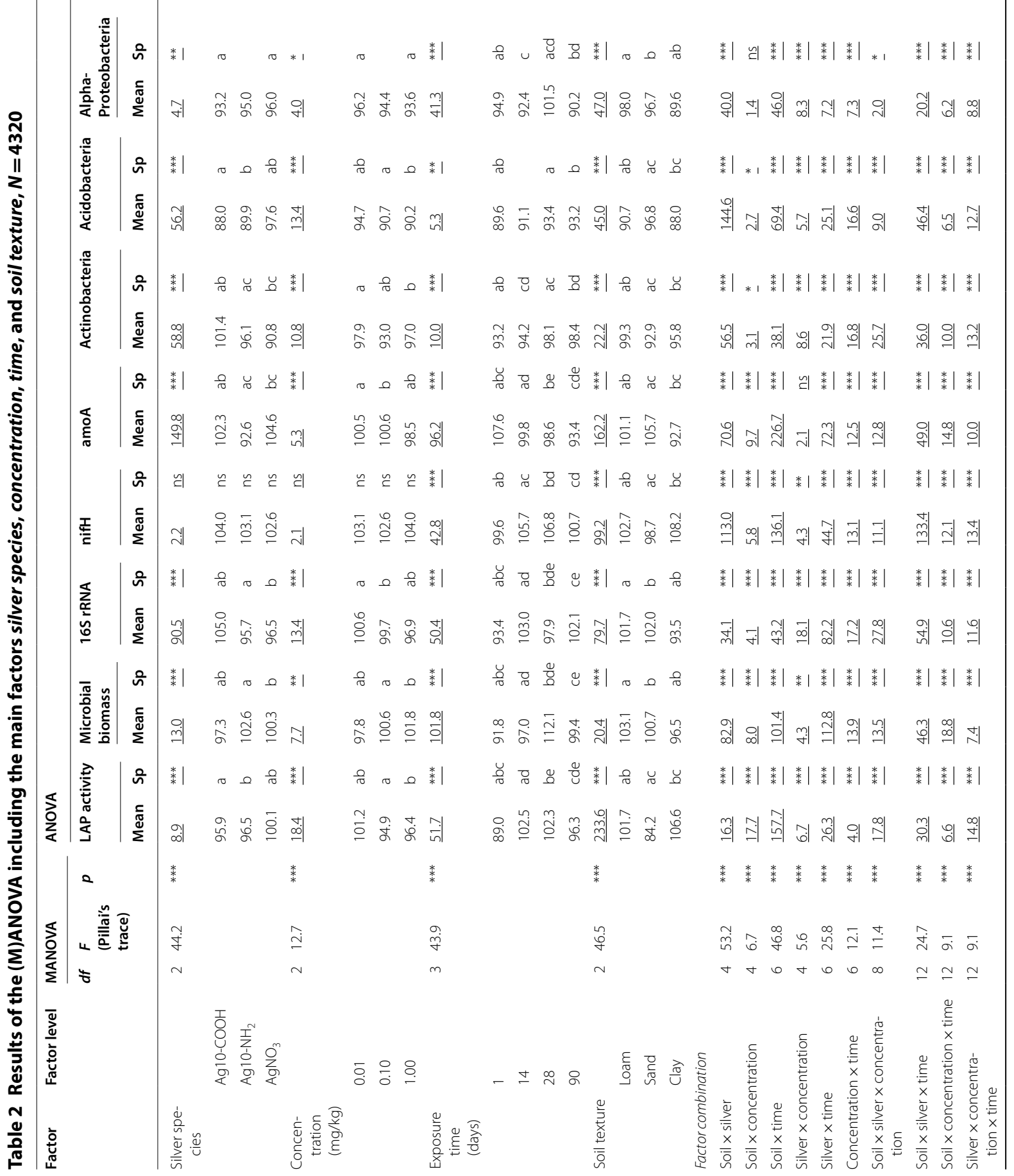




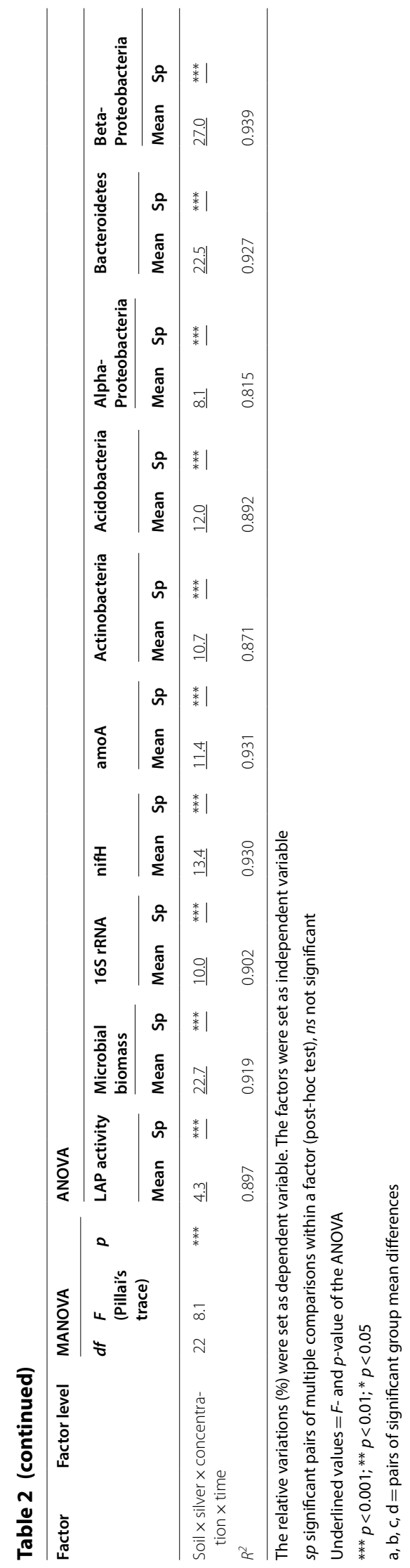



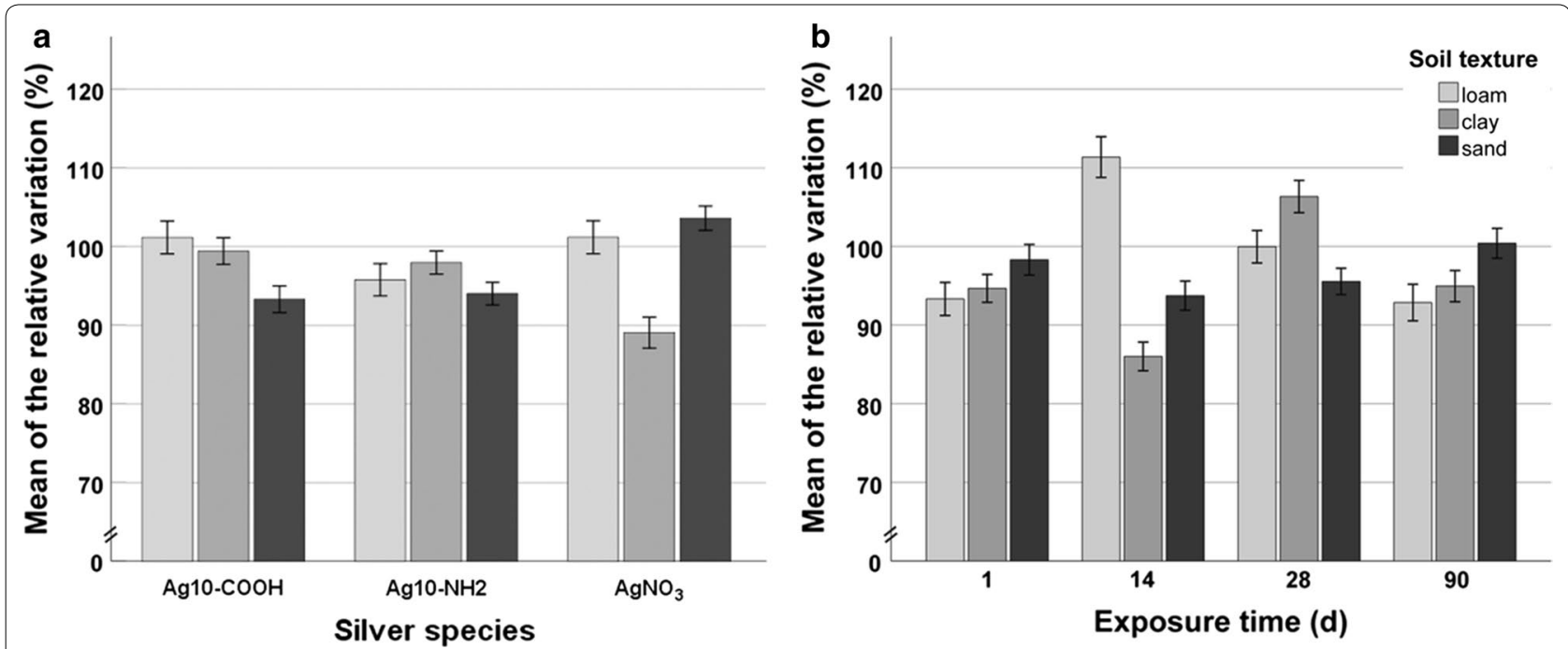

Fig. 4 Impact of factor combinations on the entirety of the relative variation of the biological parameters. a Silver species $\times$ soil texture, $\mathbf{b}$ exposure time $\times$ soil texture. The error bars represent the $95 \%$ confidence interval. $N=4320$. The relative variations (\%) were set as dependent variable. The factors were set as independent variable. To calculate the impact of the factor combination silver species $\times$ soil texture on the relative variation of the biological parameters, the relative variations were unconnected to the factors concentration and exposure time (a). To calculate the impact of the factor combination exposure time $\times$ soil texture on the relative variation of the biological parameters, the relative variations were unconnected to the factors concentration and silver species (b)

The relative variation of the biological parameter in the presence of the different silver and nitrate concentrations changed significantly with the exposure time $(p=0.000)$ (Fig. 5a). After a decrease of the relative variation on day 1 , the relative variation increased by $14.5 \%$ on day 14 to $109.4 \%$ ( $p=0.000)$. Within the mid-term exposure, a similar, but negatively change of $10.8 \%$ could be observed at day $28(p=0.000)$. At the end of the experiment, a further, but not significant decline of the relative variation of the biological parameter could be observed (Fig. 5a).

By means of the entirety of the relative variation of the biological parameters the means of AgPure (96.4\%) and Ag10- $\mathrm{NH}_{2}$ (95.8\%) caused no significant pairwise disparity in their effect characteristic (Fig. 5b). This could also be stated for the means of Ag10-COOH (101.2\%), $\mathrm{AgNO}_{3}(101.2 \%)$ and $\mathrm{KNO}_{3}$ (104.2\%) (Fig. 5b). In contrast, AgPure and Ag10- $\mathrm{NH}_{2}$ each differed significantly from Ag10-COOH, $\mathrm{AgNO}_{3}$ and $\mathrm{KNO}_{3}$ in their pairwise comparisons $(p \leq 0.007)$.

The results of the factor combinations of the multivariate multi-factorial analysis revealed lower $F$-values than for the main factors agent species and exposure time individually. However, the factor combination agent species $\times$ exposure time was scored as the strongest option $(F=14.5)$ within the factor combination possibilities (Table 3). At this, 1 day exposure demonstrated Ag10- $\mathrm{NH}_{2}(89.8 \%)$ as the agent species with the highest influence on the relative variation of the biological parameter in the loamy soil, followed by $\mathrm{Ag} 10-\mathrm{COOH}$
(92.3\%) (Fig. 6). AgPure and $\mathrm{AgNO}_{3}$ showed only small influences on the relative variation. Between $\mathrm{AgNO}_{3}$ and $\mathrm{KNO}_{3}$ no significant pairwise difference could be observed. At day 14, all agent species provoked an increase of the relative variation. The biological parameter were stimulated by $1.8 \%$ (AgPure) to $16.0 \%\left(\mathrm{AgNO}_{3}\right)$ $(p=0.000)$. Again, between $\mathrm{AgNO}_{3}$ and $\mathrm{KNO}_{3}$ no significant pairwise difference could be observed. After 4 weeks of exposure, the stimulating effect of all agent species weakened (Fig. 6). In the case of Ag10-COOH and $\mathrm{KNO}_{3}$ a decrease of the relative variation of $7.3 \%$ and $5.8 \%$, respectively, could be observed. The strongest effects on the relative variation of the biological parameters due to the different agent species were created at day 90 (Fig. 6). The agent species Ag10-COOH and $\mathrm{KNO}_{3}$ provoked significant stimulations of the biological parameters of $12.5 \%$ and $15.1 \%$, respectively (Table 4 ). In contrast, AgPure, $\mathrm{AgNO}_{3}$ and $\mathrm{Ag} 10-\mathrm{NH}_{2}$ significantly diminished the relative variation by $14.8,16.3$ and $17.8 \%$, respectively (Table 4).

\section{Discussion}

The soil microbial community is responsible for several soil ecosystem services, like the recycling of organic matter, the soil fertility and structure, the biogeochemical nutrient cycles, the toxin degradation and the pathogen control [49-53]. Especially bacteria are the main performer of functional processes, which are integral for maintenance of healthy soil environments [54]. 


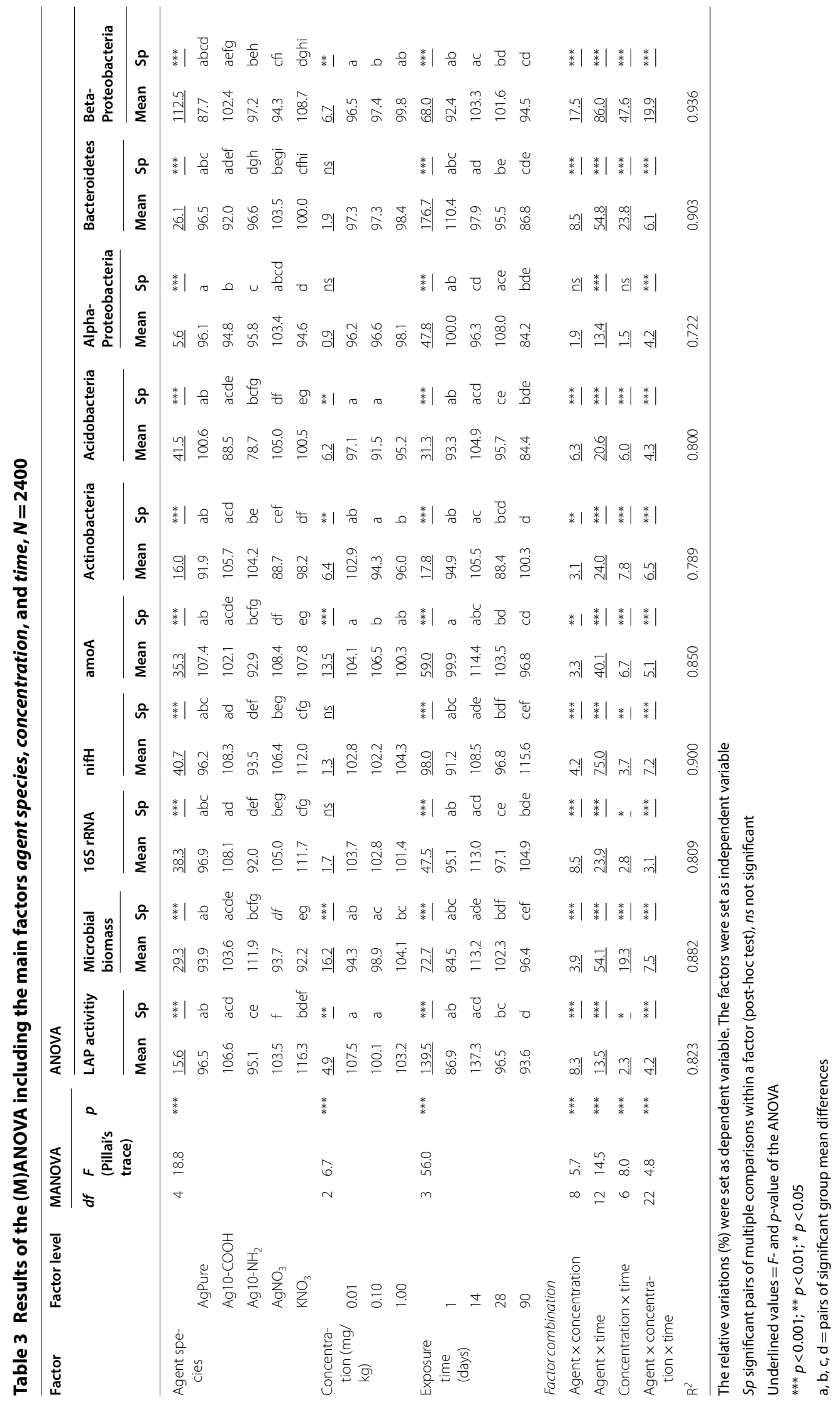



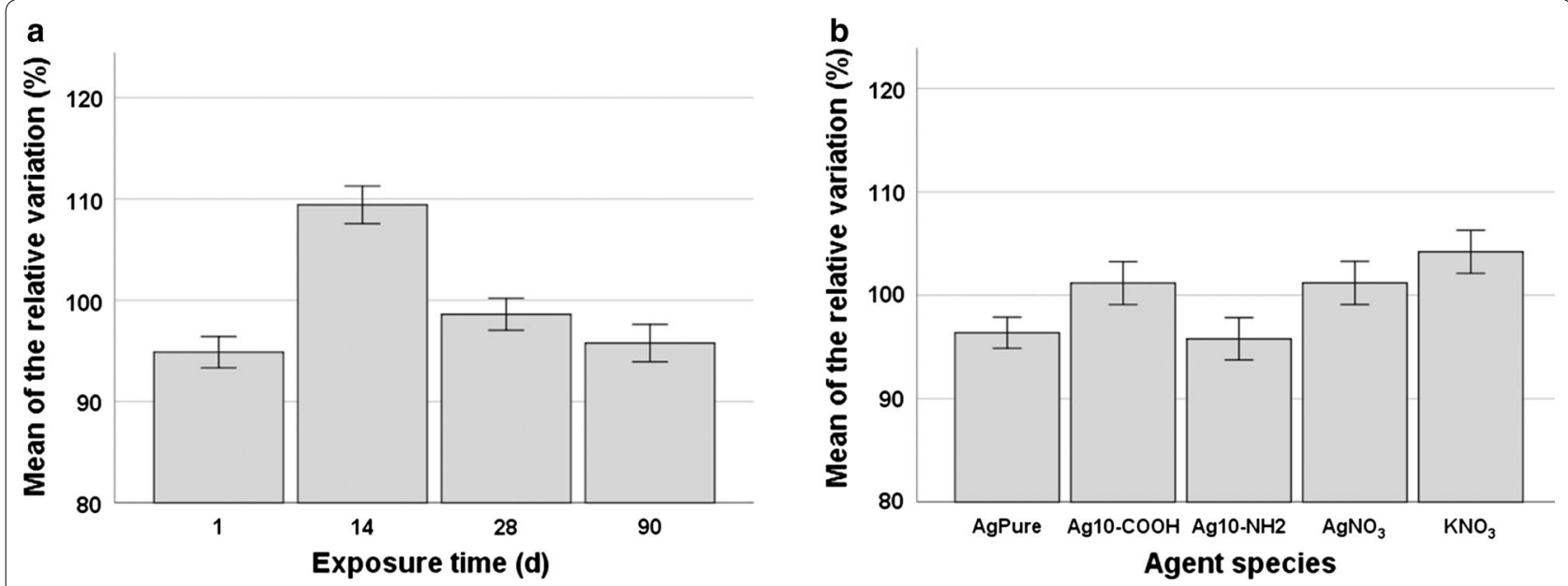

Fig. 5 Impact of the factors exposure time (a) and agent species (b) in a loamy soil. The error bars represent the $95 \%$ confidence interval. $N=2400$ The relative variations (\%) were set as dependent variable. The factors were set as independent variable. To calculate the effect of the exposure time on the relative variation of the biological parameters, the relative variations were calculated unconnected to the factors concentration and agent species (a). For the calculation of the effect expression of the factor agent species, the relative variations were unconnected to the factors concentration and exposure time (b)

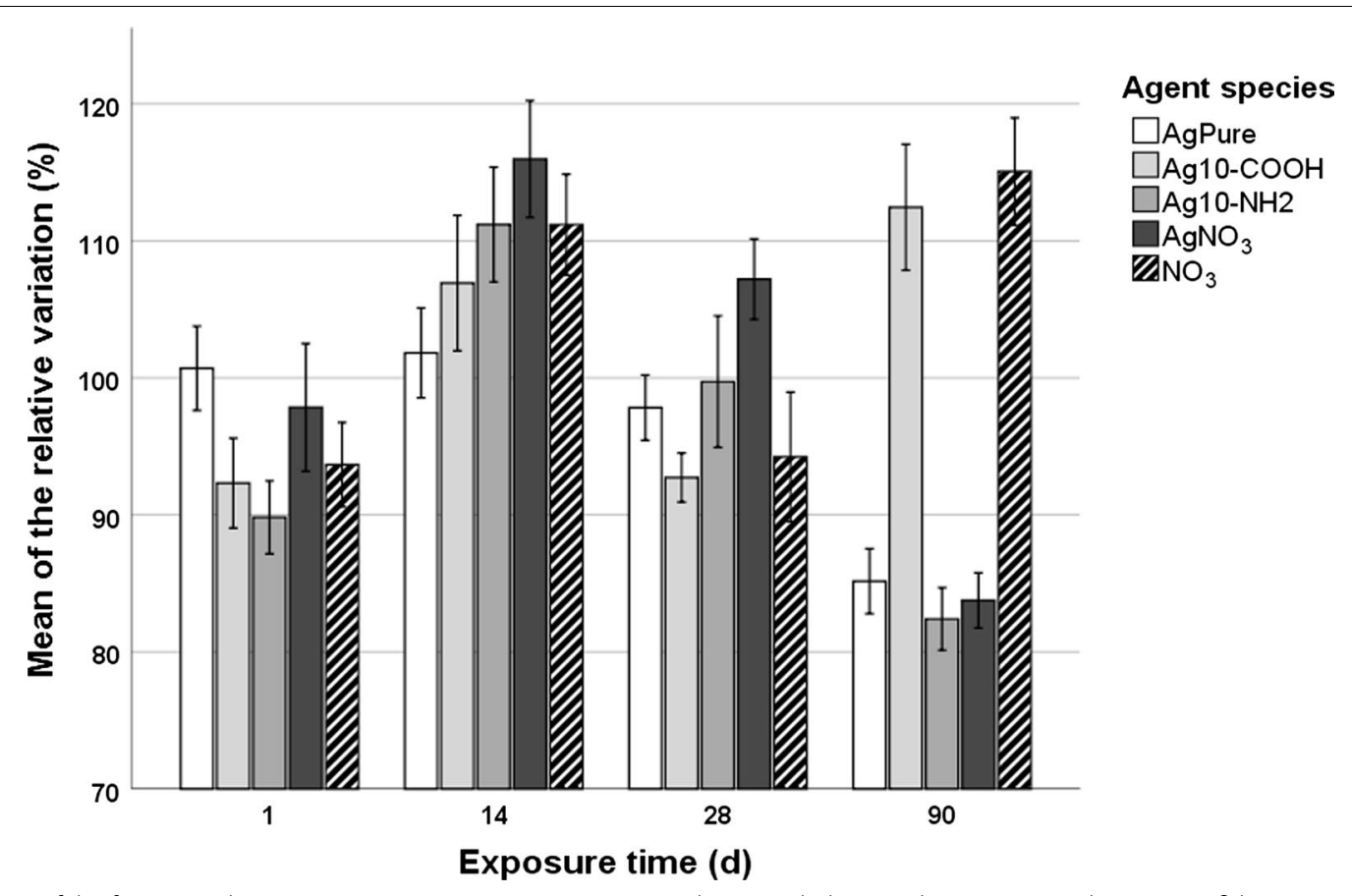

Fig. 6 Impact of the factor combinations exposure time $\times$ agent species in a loamy soil. The error bars represent the 95\% confidence interval. $N=240$. The relative variations (\%) were set as dependent variable. The factors were set as independent variable. To calculate the impact of the factor combination exposure time $\times$ agent species on the relative variation of the biological parameters, the relative variations were unconnected to the factor concentration

In this study, we used the DNA content of soil samples as a proxy for the microbial biomass and the abundance of 16S rRNA genes as an indicator of bacterial abundance. Furthermore, we measured LAP activity as well as the gene abundance of nifH and $a m o A$ as proxies for the nitrogen cycle, which drives many ecosystem activities in soils, including plant production $[40,41,55]$. Finally, we documented the response of 
Table 4 Pairwise comparisons $(p)$ of the post-hoc test, $N=\mathbf{2 4 0 0}$

\begin{tabular}{|c|c|c|c|c|c|}
\hline & AgPure & $\mathrm{Ag} 10-\mathrm{COOH}$ & Ag10- $\mathrm{NH}_{2}$ & $\mathrm{AgNO}_{3}$ & $\mathrm{KNO}_{3}$ \\
\hline \multicolumn{6}{|l|}{1 days } \\
\hline AgPure & & 0.007 & 0.000 & ns & 0.042 \\
\hline $\mathrm{Ag} 10-\mathrm{COOH}$ & 0.007 & & ns & ns & ns \\
\hline $\mathrm{Ag} 10-\mathrm{NH}_{2}$ & 0.000 & 0.000 & & 0.011 & ns \\
\hline $\mathrm{AgNO}_{3}$ & ns & ns & 0.011 & & ns \\
\hline $\mathrm{KNO}_{3}$ & 0.042 & ns & ns & ns & \\
\hline \multicolumn{6}{|l|}{14 days } \\
\hline AgPure & ns & ns & 0.015 & 0.000 & 0.015 \\
\hline $\mathrm{Ag} 10-\mathrm{COOH}$ & ns & & ns & 0.021 & ns \\
\hline $\mathrm{Ag} 10-\mathrm{NH}_{2}$ & 0.015 & ns & & ns & ns \\
\hline $\mathrm{AgNO}_{3}$ & 0.000 & 0.021 & ns & & ns \\
\hline $\mathrm{KNO}_{3}$ & 0.015 & ns & ns & ns & ns \\
\hline \multicolumn{6}{|l|}{28 days } \\
\hline AgPure & & ns & ns & 0.001 & ns \\
\hline $\mathrm{Ag} 10-\mathrm{COOH}$ & ns & & 0.037 & 0.000 & ns \\
\hline $\mathrm{Ag} 10-\mathrm{NH}_{2}$ & ns & 0.037 & & 0.018 & ns \\
\hline $\mathrm{AgNO}_{3}$ & 0.001 & 0.000 & 0.018 & & 0.000 \\
\hline $\mathrm{KNO}_{3}$ & ns & ns & ns & 0.000 & \\
\hline \multicolumn{6}{|l|}{90 days } \\
\hline AgPure & & 0.000 & ns & ns & 0.000 \\
\hline $\mathrm{Ag} 10-\mathrm{COOH}$ & 0.000 & & 0.000 & 0.000 & ns \\
\hline $\mathrm{Ag} 10-\mathrm{NH}_{2}$ & ns & 0.000 & & ns & 0.000 \\
\hline $\mathrm{AgNO}_{3}$ & ns & 0.000 & ns & & 0.000 \\
\hline $\mathrm{KNO}_{3}$ & 0.000 & ns & 0.000 & 0.000 & ns \\
\hline
\end{tabular}

Comparisons of the relative variation of the biological parameter to untreated control in dependence of the factors exposure time and agent species in the loamy soil. Only significant pairs were stated by their $p$ value. In case of "ns" no significant comparison could be observed

Acidobacteria, Actinobacteria, alpha-Proteobacteria, Bacteroidetes and beta-Proteobacteria as representatives of the main soil bacterial phyla. Despite the phylogenetic diversity [56], not cultivability [57] and functional redundancy [58] still make it difficult to link members of bacterial phyla in soils with their function, some specific soil functions could be assigned to specific soil bacteria [41, 59-63].

The influence of freezing and defrosting is known to influence the structure and function of microbial communities [64, 65]. Nevertheless, this procedure was executed considering the high amount of samples to be processed. Since this method was applied to all samples, the results were comparable and give statistical inferences about the influence of the factors silver/agent species, concentration, exposure time and soil texture.

\section{Silver/agent species}

The main determining factor silver species caused almost significant effects on the investigated biological parameters of the three test soils (Table 2), whereby the main factor agent species caused significant effects on all investigated biological parameters in the loamy soil (Table 3).

In a simultaneous consideration of all biological parameters by the MANOVAs, an increase in the toxicity of $\mathrm{KNO}_{3} \quad(104.2 \%)=\mathrm{Ag} 10-\mathrm{COOH}$ $(98.0 \% / 101.2 \%)=\mathrm{AgNO}_{3} \quad(97.95 \% / 101.2 \%)<$ AgPure $(96.4 \%)=\mathrm{Ag} 10-\mathrm{NH}_{2}(95.9 \% / 95.8 \%)$ could be observed, whereby between $\mathrm{Ag} 10-\mathrm{COOH}$ and $\mathrm{AgNO}_{3}$ no significant pairwise difference could be calculated (Additional file 1: Fig. S1). Values of the main factor agent species are shown in italic.

The coating of NP is crucial for their reactivity and physico-chemical transformations, such as the dissolution rate, the availability of surface areas, the surface charge, the aggregation rate and the long-term stability $[27,66,67]$. Analysis of the $\zeta$-potential of the AgNP under different $\mathrm{pH}$ values (Fig. 2b, d), indicated no significant impact of $\mathrm{pH}$ on $\zeta$-potential of the Ag10- $\mathrm{COOH}$ particles. The high negative $\zeta$-potentials of $-33.9 \pm 1.8 \mathrm{mV}$ at $\mathrm{pH} 4$ and $-39.4 \pm 1.5 \mathrm{mV}$ at $\mathrm{pH} 7.4$ of the Ag10$\mathrm{COOH}$ indicate high stability of these nanoparticles. The $\mathrm{COOH}$-coating could minimize $\mathrm{Ag}^{+}$ion release as well as direct contact of the AgNP with microorganisms or soil compartments such as clay particles or natural organic matter due to their function as a physical barrier [27, 31, 66]. The investigation of Long et al. [68] confirmed this hypothesis. They examined the $\mathrm{Ag}^{+}$release and toxicity of different coated AgNP which were very similar to our Ag10-COOH particles and observed only a slightly release of $\mathrm{Ag}^{+}$and a lower associated toxicity to Escherichia coli. In addition, the negative surface charge could led to an attachment of soil cations such as $\mathrm{Ca}^{2+}, \mathrm{Mg}^{2+}$ or $\mathrm{K}^{+}$on the Ag10-COOH particles and an increase of their physico-chemical barrier.

Furthermore, the coating of AgNP plays a crucial role in determining their cellular uptake mechanism [26], where the negative surface charge of Ag10-COOH indicates a low affinity to negatively charged membranes of microorganisms. Nevertheless, Ag10- $\mathrm{COOH}$ induced both adverse and advantageous effects in view of the investigated individual biological parameters. Here, individual defense strategies $[28,69]$ as well as species dependent toxicological susceptibility $[17,52,70]$ of the biological parameters might be the underlying reasons.

In contrast, the $\zeta$-potential of $\mathrm{Ag} 10-\mathrm{NH}_{2}$ decreased with increasing $\mathrm{pH}$ in our experiment (Fig. 2b) and consequently a decrease of stability could be deduced in the test soils. As a consequence of the missing physico-chemical barrier a high availability of AgNP surface area as well a high release rate of $\mathrm{Ag}^{+}$ions is expectable. Both, the mean of the relative variation of all biological 
parameters $(95.9 \% / 95.8 \%)$ as well as the mean of LAP activity (96.5\%/95.1\%), 16S rRNA (95.7\%/92.0\%), amoA (92.6\%/92.9\%), Acidobacteria (89.9\%/78.7\%) and Bacteroidetes $(93.5 \% / 96.6 \%)$ (Table 2,3$)$ underlined the toxic effects of $\mathrm{Ag} 10-\mathrm{NH}_{2}$. Moreover, the positive surface charge of Ag10- $\mathrm{NH}_{2}$ could have led to a strong association with the negatively charged membranes of microorganisms [71, 72] and affect the surface tension of the membrane resulting in an increase of pore formations [26].

AgPure showed similar harmful effects such as Ag10$\mathrm{NH}_{2}$, which could be also attributed to release of $\mathrm{Ag}^{+}$ ions. Their low particle concentration, their polyacrylate stabilization and the high $\mathrm{pH}$ value of soil could have prevented initial aggregation and agglomeration of AgPure $[16,17,73]$. In addition, the high concentration of divalent cations, such as $\mathrm{Ca}^{2+}$ und $\mathrm{Mg}^{2+}$ in the loamy soil (Table 1) could promote AgPure and $\mathrm{Ag} 10-\mathrm{NH}_{2}$ dissolution, resulting in the displacement of $\mathrm{Ag}^{+}$ions from the nanoparticle surface and thus toxicity [74].

Surprisingly, the $\mathrm{AgNO}_{3}$ control documented low toxicity by average $97.95 \%$ and $101.2 \%$ of the relative variation. The use of silver nitrate is ubiquitously as control in toxicological studies with AgNP to estimate the influence of dissolved $\mathrm{Ag}^{+}$ions from AgNP $[1,4,75,76]$. Here, the toxicity order of the MANOVAs suggest a high release of $\mathrm{Ag}^{+}$ions due to $\mathrm{Ag} 10-\mathrm{COOH}(98.0 \% / 101.2 \%)$ relative to Ag10- $\mathrm{NH}_{2}(95.9 \% / 95.8 \%)$ and AgPure (96.4\%) and thus a high direct toxic impact of $\mathrm{Ag} 10-\mathrm{NH}_{2}$ and AgPure NP itself. However, an individual view on the biological parameters with regard to the ANOVAs resulted in a different manner. The bacterial abundance (S16 rRNA) and the abundance of Actinobacteria were stimulated by Ag10-COOH exposure and diminished by $\mathrm{AgNO}_{3}$, whereas LAP activity, microbial biomass and Acidobacteria were stimulated or not influenced by $\mathrm{AgNO}_{3}$ and diminished by Ag10-COOH (Table 2). These individual responses of the biological parameters explain the majority of significant mean differences found between Ag10$\mathrm{COOH}$ and $\mathrm{AgNO}_{3}$ within the main factors silver species. By averaging MANOVA, these important observations are lost and could have led to deceptive conclusions. Based on the individual ANOVAs (Tables 2, 3), as well as the particle and soil characterizations, the hypothesis of a high release of $\mathrm{Ag}^{+}$by $\mathrm{Ag} 10-\mathrm{COOH}$ should be excluded and could be related rather to $\mathrm{Ag} 10-\mathrm{NH}_{2}$ and AgPure.

In detail, the presented results in Tables 2 and 3 revealed no or stimulation effects due to $\mathrm{AgNO}_{3}$ in case of LAP, amoA, Acidobacteria and Bacteroidetes, whereas the used AgNP caused predominantly lower relative variations of these biological parameters. Similar observations were documented in short-term studies dealing with the effect of low concentrations of AgNP and
$\mathrm{AgNO}_{3}$ on organisms related to nitrogen cycle, where $\mathrm{AgNO}_{3}$ might cause lower or even stimulating effects relative to the AgNP. Quite recently, we observed stimulating effects by $\mathrm{AgNO}_{3}$ to ammonia-oxidizing and nitrogen fixing bacteria after short-term exposure, whereby AgNP led to their decrease [16]. Schlich et al. [77] documented a significant stimulation of the nitrite production after 7 day exposure to $0.19 \mathrm{mg} / \mathrm{kg} \mathrm{AgNO}_{3}$ up to $19.4 \%$, whereby AgNP caused an inhibition. Yang et al. [78] found that $2.5 \mu \mathrm{g} / \mathrm{L}$ of $\mathrm{Ag}^{+}$as $\mathrm{AgNO}_{3}$ upregulated AMOA genes $a m o A 1$ and $a m o C 2$ by 2.1 by 3.3 -fold. Furthermore, Choi et al. [79], Masrahi et al. [24] and Liang et al. [80] observed lower effects on microbial nitrification due to $\mathrm{AgNO}_{3}$ relative to AgNP after short-term exposure. Here, in view of the very similar effect expressions of $\mathrm{AgNO}_{3}(101.2 \%)$ and $\mathrm{KNO}_{3}(104.2 \%)$ we suspect, that the nitrate contained in the $\mathrm{AgNO}_{3}$ might also impact the biological parameter such as the silver itself in the $\mathrm{AgNO}_{3}$ control. LAP activity and amoA are proxies for the nitrogen cycle. Because of the spatial structure imposed by soil particles resulting in local variations in oxygen availability over small distance [81], both aerobic and anaerobic conditions can be found in the same soil sample. Thus, $\mathrm{AgNO}_{3}$ control could act as substrate for nitrate reducing bacteria, such as gamma-Proteobacteria or Acidobacteria [63, 82, 83], which were less sensitive to $\mathrm{AgNP}$ or $\mathrm{Ag}^{+}$in form of $\mathrm{AgNO}_{3}[78,84,85]$ and promoted their increase due to nitrate utilization via denitrification and/or dissimilatory nitrate reduction [81, 83] resulting in new nitrogen sources for the ammonia-oxidizing and nitrogen fixing bacteria.

The increase of the abundance of Bacteroidetes might be the result of harboring silver resistance genes [69] and simultaneously increased availability of carbon through decreased silver-sensitive microbes, which promoted the as r-strategist know Bacteroidetes [56]. Nevertheless, the average factor expression of $\mathrm{AgNO}_{3}$ in case of Actinobacteria $(90.8 \% / 88.7 \%)$ and beta-Proteobacteria $(94.0 \% / 94.3 \%)$ (Tables 2,3$)$ indicated still harmful effects. Consequently, there could be an interplay of stimulating and detrimental effects, which might underlay in the agent itself, but also in consequential shifts of the microbial community and nutrient availability.

The $F$-values of the biological parameters in both MANOVAs indicated the main factors silver species and agent species as strong options to explain large parts of the variances compared to the error variances (Tables 2,3). With respect to the three different used AgNP, our results confirmed a distinctive impact of the AgNP functionalization on their fate and toxicity in the soil environment. The general applicability of $\mathrm{AgNO}_{3}$ as suitable positive control should be subject of further investigations. 


\section{Concentration}

The main determining factor concentration caused as well almost significant effects on the investigated biological parameters in the three test soils (Table 2). The majority of significant mean differences in the factor were found for 0.01 and $1.00 \mathrm{mg} / \mathrm{kg}$ silver. Here, the toxicity of the silver species increased predominantly with increasing concentrations (Additional file 1: Fig. S2), which was already observed in a variety of recent soil studies $[5,24$, $86,87]$.

The concentration of AgNP strongly influences their physico-chemical transformation. Once released into the environment, AgNP concentration is crucial for dissolution and aggregation mechanisms [28]. Merrifield et al. [63] documented AgNP homoaggregation as insignificant at realistic environmental concentrations, whereby dissolution and also heteroaggregation processes were more likely. Based on the low test concentrations of $0.01-$ $1.00 \mathrm{mg} / \mathrm{kg}$ silver, dissolution seemed to be the most probable transformation type in our study. Dissolution hypothesis was supported by the average high $\mathrm{pH}$ value of soils that could have prevented initial aggregation and agglomeration of AgNP [73] as well as the average high concentration of divalent cations, such as $\mathrm{Ca}^{2+}$ und $\mathrm{Mg}^{2+}$ (Table 1), which promoted AgNP dissolution and resulted in the displacement of $\mathrm{Ag}^{+}$ions from the nanoparticle surface [74]. Furthermore, the high $\zeta$-potentials of +36.8 and $+39.2 \mathrm{mV}$ for $\mathrm{Ag} 10-\mathrm{NH}_{2}$ as well as of -33.9 and $-39.4 \mathrm{mV}$ for $\mathrm{Ag} 10-\mathrm{COOH}$ at $\mathrm{pH} 4$ and 7.4, respectively, indicated high interparticular repulsive forces, which diminished the aggregation probability due to high stability [88]. However, according to Klitzke et al. [14] a decrease of $\zeta$-potential after AgNP exposure to soil solution has to be assumed.

A direct interaction of the microbes with the differently charged AgNP is also conceivable. However, the relative variation of the biological parameters differed only by $2.0 \%$ between 0.01 and $1.00 \mathrm{mg} / \mathrm{kg}$ silver. This low effect expression can be attributed to the low bioavailability of the silver species as well as to bacterial resistance mechanisms. The released silver ions could bind to clay particles $[19,33]$ or organic material $[20,89,90]$ and thus be less bioavailable. In addition, the likelihood of a microbe to encounter a silver particle or ion is generally low concerning the applied low test concentrations. In the event of a coincidence, bacteria possess various commonly defense mechanisms to escape the toxic influence of silver, such as the thickness of their peptidoglycan-membrane as the first line of defense [91], efflux systems to extrude heavy metal ions $[4,92,93]$ and the production of extracellular proteins and exopolysaccharide [94] to neutralize small amounts of toxic compounds [95, 96]. Furthermore, some bacteria obtain specific silver resistance genes, which encode periplasmic silver-specific binding protein (SilE), silver efflux pumps (P-type ATPase), and membrane potential-dependent polypeptide cations/proton antiporter (SilCBA) [4].

Nevertheless, compared to the $F$-values of the other main factors, the factor concentration could elucidate the least variance of the mean values considering all variables (Tables 2, 3). Based on our results, the main factor concentration at environmentally relevant levels has, therefore, only a very weak influence on the AgNP effect characteristics respecting the microbial community in soils.

\section{Exposure time}

The main determining factor exposure time caused consistently significant effects on the investigated biological parameters in the three test soils after silver exposure (Table 2), with the majority of significant mean differences between the factor expressions 1 day and $28 \mathrm{~d}$. With the exception of the relative variation of the $\mathrm{Bac}$ teroidetes and the ammonia-oxidizing bacteria (amo $A$ ), all biological parameter were negatively affected at day 1 (Table 2). This observation was rather unusual, because several studies measured high and fast sensitivity of ammonia-oxidizing bacteria with AgNP and $\mathrm{AgNO}_{3}[24$, 77, 78]. Apart from that, we recently recognized a tolerance of $a m o A$ harboring bacteria after short-term exposure to AgNP [16]. Furthermore, Schlich et al. [77] and Samarajeewa et al. [86] observed stimulatory effects with ionic and nanoparticulate silver to ammonia-oxidizing bacteria, which could be ascribed to hormone-like responses to low silver concentrations. By contrast, the stimulation of Bacteroidetes due to silver addition was in agreement with previous observations [52, 69, 70, 97, 98]. They exhibit silver resistance genes [78].

As the exposure time increased until day 28, the injury on the microbial community decreased (Additional file 1: Fig. S3). It is likely that the short-term effects after 1 day were observed as a result of the initial release of bioavailable $\mathrm{Ag}^{+}$by $\mathrm{AgNP}$ and $\mathrm{AgNO}_{3}$, causing toxic effects on the microbial community. Dissolution experiments $[99,100]$ verified fast solubility of AgNP in soils. With increasing exposure time, the silver species became less bioavailable due to interactions with organic matter, clay minerals or pedogenic oxides [19,33]. Furthermore, upcoming mechanisms such as self-protection [4, 9193, 95, 96], resistance [4], resilience [58] and/or cryptic growth [101], might also be possible explanations for the limited effects on the microbial community in the soils.

Results of the ANOVA using data of the loamy soil only documented a similar trend (Table 3 ). Here, all biological parameters were also negatively affected at day 1 , 
with the exception of the relative variation of the Bacteroidetes and the ammonia-oxidizing bacteria (amoA). In virtue of the high clay content (approximately 30\%) of the loamy soil and its high content of organic carbon (2.9\%) (Table 1), the retention of AgNP and $\mathrm{Ag}^{+}$ions arose earlier and the toxicity of the agents decreased even at day 14 (Table 3) [14, 20, 102, 103].

On day 90, an impairment of the microbial community could be observed relative to day 28 for both ANOVAs (Tables 2,3). Similar trends were observed in our previous studies [16, 17]. As AgNP and $\mathrm{Ag}^{+}$ions gradually aged, they slowly returned to the biological soil system as a continuously sink of silver agents. Diez-Ortiz et al. [33] also documented a progressive increase in AgNP toxicity with time and assumed a time-dependent enlargement of silver in soil pore water due to slow dissolution.

The $F$-values of the biological parameters in both MANOVA indicated the main factor exposure time as a strong option to explain a large part of the variances compared to the error variances (Tables 2,3). Especially in case of the exclusion of the factor soil texture from the MANOVA, the factor exposure time yielded the maximum $F$-value (Table 3 ). These results strongly underline the significance of the exposure time for AgNP ecotoxicity investigations, attributable to the changes of silver bioavailability and its specification status during longterm experiments in soils.

\section{Soil texture}

Also the main factor soil texture caused significant effects on all investigated biological parameters in the three test soils (Table 2). The majority of significant mean differences were found between the loamy soil and the clayey soil. This was noticeable, because their investigated soil characteristics such as $\mathrm{pH}, \mathrm{TOC}, \mathrm{TN}$ and CEC were very similar. The most distinct difference resulted from their grain size distributions of clay $(45-65 \%$ vs. $25-35 \%)$ and sand (5-40\% vs. 25-45\%) (Table 1). Actually, recent studies have shown a positive correlation between the clay content of soils and the toxicity of AgNP: lower grain size of soils resulted in lower toxicity of AgNP [19, $23,25]$. Indeed, this was appropriate for the sandy soil with a mean of $97.0 \%$ and the loamy soil with a mean of $99.4 \%$ relative abundance of all biological parameters (Additional file 1: Fig. S4). However, the mean of the relative abundance of the clayey soil (95.5\%) illustrated the opposed situation: lower grain size of the clayey soil resulted in higher toxicity of silver (Additional file 1: Fig. S4). In fact, not only the particle size distribution can be responsible for the silver toxicity. Schlich and HundRinke [19] documented that the highest AgNP toxicity was associated with more acidic soils, whereas the lowest toxicity was associated with more alkaline soils. They supposed that the soil $\mathrm{pH}$ value influences AgNP dissolution and the release of ions [19]. Similarly, this could be observed for the loamy soil $(\mathrm{pH}=7.2)$ and the sandy soil $(\mathrm{pH}=3.2)$ in this study (Table 2$)$. At the same time, the results of the clayey soil with a $\mathrm{pH}$ value of 7.4 seemed to disagree again with the hypothesis.

The results of the factor combination silver species $\times$ soil texture (Fig. 4a) might elucidate the crux of the observed mean silver toxicity order loamy soil $<$ sandy soil < clayey soil. In case of Ag10- $\mathrm{NH}_{2}$ and $\mathrm{Ag} 10-\mathrm{COOH}$, the loamy and the clayey soil exhibited lower toxicity compared to the sandy soil (Fig. 4a). This confirmed the positive correlation between the grain size distribution of soils and the toxicity of AgNP as well as the association of high AgNP toxicity by more acidic soils [19, 23, 25]. In contrast, $\mathrm{AgNO}_{3}$ caused a strong decrease of the entirety of the relative variation of the biological parameters in the clayey soil (Fig. 4a), which caused an overwhelmed influence on the average formation in the MANOVA of the silver species. This indicated a completely different fate of $\mathrm{AgNO}_{3}$ compared to AgNP in the test soils.

\section{Soil texturex silver species}

The factor combination soil texture $\times$ silver species yielded the highest $F$-value in the MANOVA considering the entirety of the relative variation of the biological parameters (Table 2).

With regard to the investigated AgNP it could be observed that their toxicity was lower in the loamy and clayey soil than in the sandy soil (Fig. 4a). In case of Ag10- $\mathrm{NH}_{2}$ the high availability of soil cations in the loamy and the clayey soil (Table 1) might have promoted the dissolution of the lower stable AgNP [14], resulting in the release of $\mathrm{Ag}^{+}$ions. These were bound to clay particles and became less bioavailable [33]. The absent effect of the $\mathrm{AgNO}_{3}$ control as measure for $\mathrm{Ag}^{+}$impact in the loamy soil might confirm this hypothesis. Furthermore, the high content of natural organic matter, derived by the land-uses of the loam and clay locations, could have been reduced the toxicological effects of the $\mathrm{Ag} 10-\mathrm{NH}_{2}$ due to inhibition of oxidation [104]. At this, positive charged Ag10- $\mathrm{NH}_{2}$ were adsorbed by negatively charged organic matter, which dominated now the surface properties leading to higher steric stability and thus also lower bioavailability [18].

In contrast, the sandy soil exhibited contrary soil properties and thus toxicity (Table 1). Although the low amount of soil cations reduced the dissolution affinity of AgNP, the low pH of 3.2 and the concomitant higher amount of $\mathrm{OH}^{-}$ions might decreased the $\mathrm{Ag} 10-\mathrm{NH}_{2}$ stability due to the deprotonation of the amino groups. Under aerobe conditions, AgNP oxidation followed and $\mathrm{Ag}^{+}$ions were released [104]. The small clay content of 
the sandy soil (0.0-5.0\%) did not provide enough capacity for $\mathrm{Ag}^{+}$retention resulting in direct harmful interactions of $\mathrm{Ag}^{+}$with the microorganisms, such as interactions with enzymes of the respiratory chain reaction, increase of DNA mutation frequencies or morphological changes of cell wall membrane [105]. However, the stimulating effects of the $\mathrm{AgNO}_{3}$ control on the biological parameters in the sandy soil disagreed with the $\mathrm{Ag}^{+}$dissolution theory (Fig. 4a). Therefore, it might be that the Ag10- $\mathrm{NH}_{2}$ particle itself caused the negative effects in the sandy soil. Positively charged NP were observed to strongly associate with membranes, which leads to a higher cellular uptake [26].

The lower toxicity of the Ag10-COOH relative to the Ag10- $\mathrm{NH}_{2}$ particles based in general on their higher stability and their surface barrier, which reduced $\mathrm{Ag}^{+}$dissolution. Furthermore, their negative surface charge promoted the attachment of soil cations of the loamy and the clayey soil and could have prevented direct interactions with negatively charged membranes of microorganisms [26, 27, 31, 66, 68]. Analogously to the Ag10- $\mathrm{NH}_{2}$, Ag10- $\mathrm{COOH}$ showed strongest toxicity in the sandy soil (Fig. 4a). Here, interactions with soil cations as well as natural organic material seemed to be less probable considering the soil and AgNP characteristics (Table 1). In addition to a low oxidation of $\mathrm{Ag} 10-\mathrm{COOH}$ and the concomitant lower $\mathrm{Ag}^{+}$release, a direct interaction of these AgNP with microorganisms can be assumed. An internalization of negatively charged nanoparticles could be occured through nonspecific binding and clustering of the particles on cationic sites on the plasma membrane and subsequent endocytosis or by direct diffusion through the cell membrane [106]. Here, Ag10-COOH could act as a trojan horse: metabolization processes in food vacuoles and lysosomes allow the uncoating of AgNP and enable the direct release of $\mathrm{Ag}^{+}$ions into the cytoplasm causing intracellular damages [32, 107].

However, there is always a challenge to accurately differentiate what proportion of the toxicity is from the ionic form and what proportion of the nanoform [76]. For resolving this question, $\mathrm{AgNO}_{3}$ was used as measure for $\mathrm{Ag}^{+}$impact in our study. Results of silver nitrate exposure in the loamy soil confirmed their low contribution to the AgNP toxicity (Fig. $4 \mathrm{a}$ ). $\mathrm{Ag}^{+}$ions seemed to be bound to clay particles or other soil compartments and became less bioavailable. Conspicuously, $\mathrm{AgNO}_{3}$ caused the highest toxicity in the clayey soil and a low stimulation in the sandy soil. In fact, Schlich and Hund-Rinke [19] observed also a lower toxicity of $\mathrm{AgNO}_{3}$ compared to AgNP in a sandy soil (RefeSol 04A) investigating the potential ammonium oxidation, but there was no promotion. The high toxicity of $\mathrm{AgNO}_{3}$ in the clayey soil resulted by a decrease of the bacterial taxa, whereas LAP activity, nifH and $a m o A$ were hardly influenced or even stimulated (data not shown). In case of the proxies for nitrogen cycle, we suspect a significant portion of the nitrate compound of the $\mathrm{AgNO}_{3}$ control in the results. However, reasons for the detrimental effect on the bacterial structure were intricate to find. Probably, interactions with existing soil contaminants could be a reason for the high $\mathrm{AgNO}_{3}$ toxicity. The clay location was farmed and treated with herbicides and pesticides. With this, $\mathrm{AgNO}_{3}$ might have been bound to such contaminants, thus creating a new toxic agent. For example, Uwizeyimana et al. [108] indicated that pesticide and metal mixtures negatively affected earthworms. However, detailed studies on the impact of nanoparticle-pesticide combinations on microbial community in soils are currently lacking, but necessary to perform a comprehensive risk assessment of AgNP in soils.

\section{Soil texturex exposure time}

The factor combination soil texture $\times$ exposure time revealed the second highest $F$-value of 46.8 in the MANOVA (Table 2). With regard to the results in Fig. $4 \mathrm{~b}$, it could be clearly observed, that the spans of the effect characteristics of the individual soils differ significantly from each other during the four examination dates. While the effect levels in the sandy soil on days 1, 14, 28 and 90 extended over an amount of $6.3 \%$ (lowest value of $93.7 \%$ on day 14 , highest value of $100.0 \%$ on day 90 ), the amounts for the loamy and the clayey soil were $21.5 \%$ and $20.3 \%$, respectively. This indicated the loamy and the clayey soil as more complex soil systems considering the interplay of physico-chemical and biological interactions and transformations of the silver species contrary to the sandy soil. Whereas the effect expressions of the biological parameters in the sandy soil were indicative for consistent conditions, the effect expressions of the loamy and the clayey soil suggested a variety of temporal changes in the complex soil-time framework.

In case of the sandy soil it can be assumed, that there were continuously barely interactions of the silver species with the soil type characteristics, causing throughout similar effect expressions. In addition, the indigenous microbial community might show no observable adaption ability over time.

In contrast, the relative variations of the biological parameters in the loamy and the clayey soil differed not only in dependence on the exposure time, but also in their effect strength from each other, although their soil characteristics were very similar (Table 1). For example, on day 14, it could be assumed for the loamy soil, that the silver species were transformed, might be bound to the clay particles or capped by organic matter [33, 104], resulting in a decrease of toxicity and a stimulation of the 
biological parameters due to their defense arsenal [4, 9193, 95, 96] (Fig. 4b). Based on the similar soil characteristics, this should be also noted for the clayey soil. However, the biological parameter was diminished by $14.0 \%$ in the clayey soil at day 14 suggesting divergent indigenous microbial communities with different capacities to resist and adapt on silver emission. Also interactions with herbicides and pesticides of the clayey soil might have led to the creation of a new toxicant, which provoked the harmful effect. At day 28, the effective expressions of the loamy and the clayey soil reproached and none or stimulating effects were documented (Fig. 4b). At this, ageing of the silver species and their return to the biological soil system could have reduced the stimulating effects on the biological parameters in the loamy soil. Contrary, the ageing in the clayey soil of the silver species or the new toxicants as well as the now developed defense mechanisms of the microbial community after 4 weeks exposure caused stimulation by $6.3 \%$ (Fig. 4b).

Based on our data, however, we can only speculate about these events. More detailed investigations are necessary to reveal the time-dependent fate of the silver bioavailability in different soils, as well as the time-dependent responses of the microbial community to these silver species. For this purpose, the development of reliable and robust analytical methods for detecting specific silver species at trace concentrations in complex matrices is a fundamental requirement. Next, batch experiments can reveal time-dependent silver transformations and the concomitant effects on the microbial community. Furthermore, it would be useful to further deepen the soil characterization to evaluate possible effects of anthropogenic residues from e.g. herbicides or pesticides on the ecotoxicological potential of silver nanoparticles.

\section{Agent species $x$ exposure time}

Regarding the MANOVA with the main factors agent species, concentration and exposure time in the loamy soil, the factor exposure time was able to explain the largest part of variance. The factor combinations achieved lower $F$-values. Nevertheless, the factor combination agent species $\times$ exposure time still achieved the highest $F$-value of 14.5 for the factor combinations. Furthermore, the results of the pairwise comparisons of the post hoc test (Table 4) as well as the ambiguous role of $\mathrm{AgNO}_{3}$ control as a measure of $\mathrm{Ag}^{+}$dissolution gave reason to pay attention to this interaction.

Short-term exposure led only to a small difference between the investigated agents AgPure, Ag10-COOH, Ag10- $\mathrm{NH}_{2}, \mathrm{AgNO}_{3}$ and $\mathrm{KNO}_{3}$ (Fig. 6). Ag10-COOH diminished the relative variations of the biological parameters by $7.7 \%$. Based on their higher stability and the short exposure time, physico-chemical transformation could be excluded and led to the assumption of direct harmful interaction of these AgNP with microorganisms. In contrast, $\mathrm{Ag} 10-\mathrm{NH}_{2}$ was reported as strong instable AgNP due to their surface functionalization. At this, higher dissolution of $\mathrm{Ag}^{+}$ions as toxicological agent might be a probable explanation for the decrease of the biological parameters by $10.2 \%$ (Fig. 6). However, relating to the low effects of the $\mathrm{AgNO}_{3}$ control (97.95\%), the $\mathrm{Ag}^{+}$ion dissolution theory seemed less likely. Therefore, a direct interaction could be assumed as well. AgPure caused on average no effects $(100.7 \%)$ on day 1 and thus proved to be inert to physico-chemical transformations after short-term exposure. The $\mathrm{KNO}_{3}$ control diminished the biological parameters on average by $6.3 \%$, but without significant difference to $\mathrm{AgNO}_{3}$ (Fig. 6, Table 4). This slightly adverse effect might be the result of $\mathrm{NO}_{2}{ }^{-}$accumulation, due to nitrate reduction $[109,110]$.

After 14 days exposure, the differences between the effect characteristics of the agent species changed. Ag10$\mathrm{NH}_{2}(111.2 \%), \mathrm{AgNO}_{3}(116.0 \%)$ as well as $\mathrm{KNO}_{3}(112.0 \%)$ stimulated the biological parameter significantly, whereas AgPure (101.8\%) and Ag10-COOH (107.0\%) caused only low stimulatory effects. In case of the silver species, their bioavailability as well as those of the released $\mathrm{Ag}^{+}$ions could be reduced at this time point due to interactions with organic matter, clay minerals or pedogenic oxides $[14,20,102,103]$. Furthermore, emerging self-protection mechanisms, such as the production of extracellular proteins or polysaccharides of the soil microbiome could neutralize toxic ions or cap AgNP $[95,96]$. In addition, resilience mechanisms $[58,78,101]$ might be possible explanations for the limited effects on the microbial community in the soil at day 14 . The increase of the biological parameter due to $\mathrm{AgNO}_{3}$ and $\mathrm{KNO}_{3}$ exposure might result by an increase of nitrate reduction and the concomitant increase of nitrogen for the microbiome [81, 83]. Due to the synergy of microbial silver resistance mechanisms as well as the nitrogen substrate source, $\mathrm{AgNO}_{3}$ increased the relative variation of the biological parameters. As already mentioned, several authors documented stimulation or minor negative effects on microorganisms related to nitrogen cycle after exposure of low concentrations of $\mathrm{AgNO}_{3}$ in short-term exposure experiments [16, 24, 77-80].

Starting by day 28 , ageing of the silver species and their slow return to the biological soil system presented a continuous sink of bioavailable silver, reducing the stimulating effects on the biological parameters (Fig. 6). An increase in AgNP toxicity with time can be linked to time-dependent enlargement of silver in soil pore water due to dissolution $[33,111]$. However, the defense arsenal of bacteria was sufficient to resist silver toxicity at day 28 . After 3 months exposure, there seemed to be a shock load of silver in case of AgPure (85.2\%), $\mathrm{Ag} 10-\mathrm{NH}_{2}(82.4 \%)$ 
and $\mathrm{AgNO}_{3}$ (83.8\%) to which the bacterial community was not immediately prepared. Small-scale bioavailability, chemical alterations and possible transformations (oxidation, reduction, dissolution, sulfidation) of AgNP and $\mathrm{Ag}^{+}[23,24,33,90,112,113]$ in the loamy soil are possible physicochemical causes for the abrupt toxicity. Furthermore, it might be assumed that after short- and mid-term adaption to the silver contamination as well as the positioning of the silver species in the soil system, the bacterial population might have lost members with silver tolerance and were unanticipatedly shocked by the return of silver toxicant at day 90 resulting in strong reductions of the biological parameters [17].

In contrast, $\mathrm{Ag} 10-\mathrm{COOH}$ caused a significant stimulation of the investigated parameters by $12.5 \%$, confirming their high stability. With prolonged exposure time, the likelihood of bounds between the negative charged Ag10-COOH and soil cations increased and with that their physico-chemical barrier, resulting in lower bioavailability. Together with the presumably low number of free $\mathrm{Ag}^{+}$ions in case of Ag10-COOH, no toxicity could be observed.

Based on the missing significant differences of $\mathrm{AgNO}_{3}$ and $\mathrm{KNO}_{3}$ at days 1 and 14, it could not be determined, if the effects were caused only by the $\mathrm{Ag}^{+}$of the $\mathrm{AgNO}_{3}$ control, but maybe due to the $\mathrm{NO}_{3}{ }^{-}$of the $\mathrm{KNO}_{3}$ control. First at the exposure times of 28 days and 90 days, significantly different effect characteristics of $\mathrm{AgNO}_{3}$ and $\mathrm{KNO}_{3}$ by $13.0 \%(p=0.000)$ and $31.5 \%(p=0.000)$ (Fig. 6 , Table 4), respectively, could be observed. This caused us to suspect, that initial at this late time points the nitrate contained in the $\mathrm{AgNO}_{3}$ control did not further exceedingly influence the results of the $\mathrm{AgNO}_{3}$ control. In consequence, especially in case of biological parameters related to nitrogen cycle, such as LAP activity or the abundance von $a m o A$ harboring bacteria, the usage of $\mathrm{AgNO}_{3}$ as proxy for $\mathrm{Ag}^{+}$release in AgNP short-term effect assessments could be deceptive. There is an urgent need for further research into the suitability of $\mathrm{AgNO}_{3}$ as a measure of $\mathrm{Ag}^{+}$release. For example, batch experiments investigating all steps within the soil nitrogen cycle (in particular nitrogen fixation, nitrification, denitrification, dissimilatory nitrate reduction to ammonium) after short- and long-term exposure of $\mathrm{AgNO}_{3}$ and $\mathrm{NO}_{3}{ }^{-}$will be helpful to resolve in detail, at which step the nitrate released from the $\mathrm{AgNO}_{3}$ control presents an advantage for the microbial community and at which step the harmful influence of the silver predominates.

\section{Conclusions}

Impacts of the factors silver species, agent species, concentration, exposure time and soil texture on the relative variation of 10 biological parameters were analysed by $16 S$ rRNA qPCR as well as fluorometric and photometric techniques. The used AgNP were characterized in detail by electron microscopy, dynamic light scattering and asymmetrical flow field-flow fractionation. Analyses of variance revealed the factors silver species, exposure time and soil texture as the most relevant determinants for the effect expressions of the biological parameters. Furthermore, the factor combinations soil texture $\times$ silver species as well as soil texture $\times$ exposure time facilitates even larger explanations of the variance of the biological parameter.

Overall, the presented results demonstrate the importance of considering several factors in the effect assessment of AgNP. Based on our study, the relationship of the soil texture $\times$ silver species is the most significant factor combination for the environmental fate and toxicities of AgNP in soils.

\section{Additional files}

Additional file 1. Characterization of AgNP.

Additional file 2. Raw data.

\section{Abbreviations}

AgNP: silver nanoparticle(s); AF4: asymmetrical flow field-flow fractionation; Ag-HPB: hydrophobic silver particle(s); DLS: dynamic light scattering; MPA: mercaptopropionic acid; NP: nanoparticle(s); PDI: polydispersity index; UPW: ultrapure water.

\section{Authors' contributions}

$\mathrm{JC}$ designed and manufactured the $\mathrm{Ag} 10-\mathrm{NH}_{2}$ and $\mathrm{Ag} 10-\mathrm{COOH}$ nanoparticles. SS performed and evaluated the transmission electron microscopy of AgNP. $\mathrm{KY}, \mathrm{MF}$, and DR performed the $\zeta$-potential and size measurements of AgNP as well as the asymmetrical flow field-flow fractionation (AF4) of AgNP. GAL and EC designed and performed the soil experiments. GAL, EC and MW analysed the data and wrote the manuscript. All authors read and approved the final manuscript.

\section{Author details \\ ${ }^{1}$ Department of Biology, Institute for Integrated Natural Sciences, University of Koblenz-Landau, Universitätsstr. 1, 56070 Koblenz, Germany. ${ }^{2}$ Fraunhofer Institute for Biomedical Engineering IBMT, Joseph-von-Fraunhofer-Weg 1 , 66280 Sulzbach, Germany. ${ }^{3}$ Postnova Analytics GmbH, Max-Planck Straße 14, 86899 Landsberg, Germany. ${ }^{4}$ Institute of Molecular Biosciences, J.W. Goethe University, Max-von-Laue-Strase 9, 60438 Frankfurt am Main, Germany. ${ }^{5}$ PlasmaChem GmbH, Schwarzschildstraße 10, 12489 Berlin, Germany. \\ ${ }^{6}$ Department of Soil Science, Faculty of Regional and Environmental Science, University of Trier, Campus II, 54286 Trier, Germany.}

\section{Acknowledgements}

We appreciate Elvira Sieberger (University of Trier) for her excellent laboratory support and assistance.

Competing interests

The authors declare that they have no competing interests.

Availability of data and materials

All datasets on which the conclusions of the paper rely are presented in the main manuscript (Additional files 1 and 2). 


\section{Consent for publication}

Not applicable.

\section{Ethics approval and consent to participate}

Not applicable.

\section{Funding}

The study was financially supported by the BMBF (Grant No. 03X0150) and the German Research Foundation (DFG Research unit FOR 1536, MA 3273/3-2).

\section{Publisher's Note}

Springer Nature remains neutral with regard to jurisdictional claims in published maps and institutional affiliations.

\section{Received: 8 December 2018 Accepted: 9 February 2019}

Published online: 26 February 2019

\section{References}

1. Reidy B, Haase A, Luch A, Dawson K, Lynch I (2013) Mechanisms of silver nanoparticle release, transformation and toxicity: a critical review of current knowledge and recommendations for future studies and applications. Materials 6:2295-2350

2. Sun TY, Mitrano DM, Bornhöft NA, Scheringer M, Hungerbühler K, Nowack B (2017) Envisioning Nano release dynamics in a changing world: using dynamic probabilistic modeling to assess future environmental emissions of engineered nanomaterials. Environ Sci Technol 51:2854-2863

3. Abbasi E, Milani M, Fekri Aval S, Kouhi M, Akbarzadeh A, Tayefi Nasrabadi H, Nikasa P, Joo SW, Hanifehpour Y, Nejati-Koshki K (2016) Silver nanoparticles: synthesis methods, bio-applications and properties. Crit Rev Microbiol 42:173-180

4. Pareek V, Gupta R, Panwar J (2018) Do physico-chemical properties of silver nanoparticles decide their interaction with biological media and bactericidal action? A review. Mater Sci Eng C 90:739-749

5. Hänsch M, Emmerling C (2010) Effects of silver nanoparticles on the microbiota and enzyme activity in soil. J Plant Nutr Soil Sci 173:554-558

6. Gottschalk F, Kost E, Nowack B (2013) Engineered nanomaterials in water and soils: a risk quantification based on probabilistic exposure and effect modeling. Environ Toxicol Chem 32:1278-1287

7. Nowack B, Baalousha M, Bornhöft N, Chaudhry Q, Cornelis G, Cotterill J, Gondikas A, Hassellöv M, Lead J, Mitrano DM (2015) Progress towards the validation of modeled environmental concentrations of engineered nanomaterials by analytical measurements. Environ Sci Nano 2:421-428

8. Sun TY, Gottschalk F, Hungerbühler K, Nowack B (2014) Comprehensive probabilistic modelling of environmental emissions of engineered nanomaterials. Environ Pollut 185:69-76

9. Gottschalk F, Sonderer T, Scholz RW, Nowack B (2009) Modeled environmental concentrations of engineered nanomaterials $\left(\mathrm{TiO}_{2}, \mathrm{ZnO}, \mathrm{Ag}\right.$, CNT, fullerenes) for different regions. Environ Sci Technol 43:9216-9222

10. Gottschalk F, Nowack B (2011) The release of engineered nanomaterials to the environment. J Environ Monit 13:1145-1155

11. Benn TM, Westerhoff P (2008) Nanoparticle silver released into water from commercially available sock fabrics. Environ Sci Technol 42:4133-4139

12. Sun TY, Conroy G, Donner E, Hungerbühler K, Lombi E, Nowack B (2015) Probabilistic modelling of engineered nanomaterial emissions to the environment: a spatio-temporal approach. Environ Sci Nano 2:340-351

13. Dale A, Casman E, Lowry G, Lead J, Viparelli E, Baalousha M (2015) Modeling nanomaterial environmental fate in aquatic systems. Environ Sci Technol 49:2587

14. Klitzke S, Metreveli G, Peters A, Schaumann GE, Lang F (2014) The fate of silver nanoparticles in soil solution-sorption of solutes and aggregation. Sci Total Environ 535:54-60

15. Holden PA, Schimel JP, Godwin HA (2014) Five reasons to use bacteria when assessing manufactured nanomaterial environmental hazards and fates. Curr Opin Biotechnol 27:73-78

16. Grün A-L, Straskraba S, Schulz S, Schloter M, Emmerling C (2018) Long-term effects of environmentally relevant concentrations of silver nanoparticles on microbial biomass, enzyme activity, and functional genes involved in the nitrogen cycle of loamy soil. J Environ Sci 69:12-22

17. Grün A-L, Emmerling C (2018) Long-term effects of environmentally relevant concentrations of silver nanoparticles on major soil bacterial phyla of a loamy soil. Environ Sci Eur 30:1-13

18. Cornelis G, Hund-Rinke K, Kuhlbusch T, Van den Brink N, Nickel C (2014) Fate and bioavailability of engineered nanoparticles in soils: a review. Crit Rev Environ Sci Technol 44:2720-2764

19. Schlich K, Hund-Rinke K (2015) Influence of soil properties on the effect of silver nanomaterials on microbial activity in five soils. Environ Pollut 196:321-330

20. Settimio L, McLaughlin MJ, Kirby JK, Langdon KA, Janik L, Smith S (2015) Complexation of silver and dissolved organic matter in soil water extracts. Environ Pollut 199:174-184

21. Bundschuh M, Filser J, Lüderwald S, McKee MS, Metreveli G, Schaumann GE, Schulz R, Wagner S (2018) Nanoparticles in the environment: where do we come from, where do we go to? Environ Sci Eur 30:1-17

22. Lowry GV, Gregory KB, Apte SC, Lead JR (2012) Transformations of nanomaterials in the environment. Environ Sci Technol 46:6893-6899

23. Pachapur VL, Larios AD, Cledón M, Brar SK, Verma M, Surampalli R (2016) Behavior and characterization of titanium dioxide and silver nanoparticles in soils. Sci Total Environ 563:933-943

24. Masrahi A, VandeVoort AR, Arai Y (2014) Effects of silver nanoparticle on soil-nitrification processes. Arch Environ Con Tox 66:504-513

25. Rahmatpour S, Shirvani M, Mosaddeghi MR, Nourbakhsh F, Bazarganipour M (2017) Dose-response effects of silver nanoparticles and silver nitrate on microbial and enzyme activities in calcareous soils. Geoderma 285:313-322

26. Saei AA, Yazdani M, Lohse SE, Bakhtiary Z, Serpooshan V, Ghavami M, Asadian M, Mashaghi S, Dreaden EC, Mashaghi A (2017) Nanoparticle surface functionality dictates cellular and systemic toxicity. Chem Mat 29:6578-6595

27. Louie SM, Tilton RD, Lowry GV (2016) Critical review: impacts of macromolecular coatings on critical physicochemical processes controlling environmental fate of nanomaterials. Environ Sci Nano 3:283-310

28. Lead JR, Batley GE, Alvarez PJ, Croteau MN, Handy RD, McLaughlin MJ, Judy JD, Schirmer K (2018) Nanomaterials in the environment: behavior, fate, bioavailability, and effects - an updated review. Environ Toxicol Chem 27:2029-2063

29. Datta LP, Chatterjee A, Acharya K, De P, Das M (2017) Enzyme responsive nucleotide functionalized silver nanoparticles with effective antimicrobial and anticancer activity. New J Chem 41:1538-1548

30. Fröhlich E (2012) The role of surface charge in cellular uptake and cytotoxicity of medical nanoparticles. Int J Nanomed 7:1-15

31. Wu F, Harper BJ, Harper SL (2017) Differential dissolution and toxicity of surface functionalized silver nanoparticles in small-scale microcosms: impacts of community complexity. Environ Sci Nano 4:359-372

32. Grün A-L, Scheid P, Hauröder B, Emmerling C, Manz W (2017) Assessment of the effect of silver nanoparticles on the relevant soil protozoan genus Acanthamoeba. J Plant Nutr Soil Sci 180:602-613

33. Diez-Ortiz M, Lahive E, George S, Ter Schure A, Van Gestel CA, Jurkschat K, Svendsen C, Spurgeon DJ (2015) Short-term soil bioassays may not reveal the full toxicity potential for nanomaterials; bioavailability and toxicity of silver ions (AgNO 3 ) and silver nanoparticles to earthworm Eisenia fetida in long-term aged soils. Environ Pollut 203:191-198

34. Zhai Y, Hunting ER, Wouterse M, Peijnenburg W, Vijver MG (2016) Silver nanoparticles, ions and shape governing soil microbial functional diversity: nano shapes micro. Front Microbiol 7:1-9

35. Marx MC, Wood M, Jarvis SC (2001) A microplate fluorimetric assay for the study of enzyme diversity in soils. Soil Biol Biochem 33:1633-1640

36. Ernst G, Henseler I, Felten D, Emmerling C (2009) Decomposition and mineralization of energy crop residues governed by earthworms. Soil Biol Biochem 41:1548-1554

37. Kreuzer K, Adamczyk J, lijima M, Wagner M, Scheu S, Bonkowski M (2006) Grazing of a common species of soil protozoa (Acanthamoeba castellanii) affects rhizosphere bacterial community composition and root architecture of rice (Oryza sativa L.). Soil Biol Biochem 38:1665-1672

38. Töwe S, Kleineidam K, Schloter M (2010) Differences in amplification efficiency of standard curves in quantitative real-time PCR assays and 
consequences for gene quantification in environmental samples. J Microbiol Methods 82:338-341

39. Bach H-J, Tomanova J, Schloter M, Munch J (2002) Enumeration of total bacteria and bacteria with genes for proteolytic activity in pure cultures and in environmental samples by quantitative PCR mediated amplification. J Microbiol Methods 49:235-245

40. Rösch C, Mergel A, Bothe H (2002) Biodiversity of denitrifying and dinitrogen-fixing bacteria in an acid forest soil. Appl Environ Microbiol 68:3818-3829

41. Rotthauwe J-H, Witzel K-P, Liesack W (1997) The ammonia monooxygenase structural gene amoA as a functional marker: molecular fine-scale analysis of natural ammonia-oxidizing populations. Appl Environ Microbiol 63:4704-4712

42. Barns SM, Takala SL, Kuske CR (1999) Wide distribution and diversity of members of the bacterial kingdom Acidobacterium in the environment. Appl Environ Microbiol 65:1731-1737

43. Muyzer G, De Waal EC, Uitterlinden AG (1993) Profiling of complex microbial populations by denaturing gradient gel electrophoresis analysis of polymerase chain reaction-amplified genes coding for $16 \mathrm{~S}$ rRNA. Appl Environ Microbiol 59:695-700

44. Stach JE, Maldonado LA, Ward AC, Goodfellow M, Bull AT (2003) New primers for the class Actinobacteria: application to marine and terrestrial environments. Environ Microbiol 5:828-841

45. Bacchetti De Gregoris T, Aldred N, Clare AS, Burgess JG (2011) Improvement of phylum- and class-specific primers for real-time PCR quantification of bacterial taxa. J Microbiol Methods 86:351-356

46. Manz W, Amann R, Ludwig W, Vancanneyt M, Schleifer K-H (1996) Application of a suite of $16 \mathrm{~S}$ rRNA-specific oligonucleotide probes designed to investigate bacteria of the phylum cytophaga-flavobacterbacteroides in the natural environment. Microbiol 142:1097-1106

47. Overmann J, Coolen MJ, Tuschak C (1999) Specific detection of different phylogenetic groups of chemocline bacteria based on PCR and denaturing gradient gel electrophoresis of $16 \mathrm{~S}$ rRNA gene fragments. Arch Microbiol 172:83-94

48. Lane D (1991) 16S/23S rRNA sequencing. In: Stackebrandt E, Goodfellow M (eds) Nucleic acid techniques in bacterial systematics. Wiley, England

49. Kuramae EE, Yergeau E, Wong LC, Pijl AS, van Veen JA, Kowalchuk GA (2012) Soil characteristics more strongly influence soil bacterial communities than land-use type. FEMS Microbiol Ecol 79:12-24

50. Kallenbach CM, Frey SD, Grandy AS (2016) Direct evidence for microbial-derived soil organic matter formation and its ecophysiological controls. Nat Commun 7:1-10

51. Ma W, Jiang S, Assemien F, Qin M, Ma B, Xie Z, Liu Y, Feng H, Du G, Ma $X$ (2016) Response of microbial functional groups involved in soil $N$ cycle to N, P and NP fertilization in Tibetan alpine meadows. Soil Biol Biochem 101:195-206

52. McGee CF, Storey S, Clipson N, Doyle E (2018) Concentration-dependent responses of soil bacterial, fungal and nitrifying communities to silver nano and micron particles. Environ Sci Pollut Res 25:18693-18704

53. Emmerling C, Schloter M, Hartmann A, Kandeler E (2002) Functional diversity of soil organisms-a review of recent research activities in Germany. J Plant Nutr Soil Sci 165:408-420

54. Rincon-Florez VA, Carvalhais LC, Schenk PM (2013) Culture-independent molecular tools for soil and rhizosphere microbiology. Diversity 5:581-612

55. Zhang X, Liu W, Schloter M, Zhang G, Chen Q, Huang J, Li L, Elser JJ, Han $X$ (2013) Response of the abundance of key soil microbial nitrogencycling genes to multi-factorial global changes. PLoS ONE 8:e76500

56. Fierer N, Bradford MA, Jackson RB (2007) Toward an ecological classification of soil bacteria. Ecology 88:1354-1364

57. Torsvik V, Øvreås L (2002) Microbial diversity and function in soil: from genes to ecosystems. Curr Opin Microbiol 5:240-245

58. Allison SD, Martiny JB (2008) Resistance, resilience, and redundancy in microbial communities. PNAS 105:11512-11519

59. Ventura M, Canchaya C, Tauch A, Chandra G, Fitzgerald GF, Chater KF, van Sinderen D (2007) Genomics of Actinobacteria: tracing the evolutionary history of an ancient phylum. Microbiol Mol Biol Rev 71:495-548
60. Zhang Y, Cong J, Lu H, Li G, Qu Y, Su X, Zhou J, Li D (2014) Community structure and elevational diversity patterns of soil Acidobacteria. J Environ Sci 26:1717-1724

61. Li X, Rui J, Xiong J, Li J, He Z, Zhou J, Yannarell AC, Mackie RI (2014) Functional potential of soil microbial communities in the maize rhizosphere. PLoS ONE 9:e112609

62. Ward NL, Challacombe JF, Janssen PH, Henrissat B, Coutinho PM, Wu M, Xie G, Haft DH, Sait M, Badger J (2009) Three genomes from the phylum Acidobacteria provide insight into the lifestyles of these microorganisms in soils. Appl Environ Microbiol 75:2046-2056

63. Kielak AM, Barreto CC, Kowalchuk GA, van Veen JA, Kuramae EE (2016) The ecology of Acidobacteria: moving beyond genes and genomes. Front Microbiol 7:1-16

64. Sharma S, Szele Z, Schilling R, Munch JC, Schloter M (2006) Influence of freeze-thaw stress on the structure and function of microbial communities and denitrifying populations in soil. 72:2148-2154

65. Feng X, Nielsen LL, Simpson MJ (2007) Responses of soil organic matter and microorganisms to freeze-thaw cycles. Soil Biol Biochem 39:2027-2037

66. Liu C, Leng W, Vikesland PJ (2018) Controlled evaluation of the impacts of surface coatings on silver nanoparticle dissolution rates. Environ Sci Technol 52:2726-2734

67. Badawy AME, Luxton TP, Silva RG, Scheckel KG, Suidan MT, Tolaymat TM (2010) Impact of environmental conditions ( $\mathrm{pH}$, ionic strength, and electrolyte type) on the surface charge and aggregation of silver nanoparticles suspensions. Environ Sci Technol 44:1260-1266

68. Long Y-M, Hu L-G, Yan X-T, Zhao X-C, Zhou Q-F, Cai Y, Jiang G-B (2017) Surface ligand controls silver ion release of nanosilver and its antibacterial activity against Escherichia coli. Int J Nanomed 12:1-14

69. Yang Y, Quensen J, Mathieu J, Wang Q, Wang J, Li M, Tiedje JM, Alvarez PJ (2014) Pyrosequencing reveals higher impact of silver nanoparticles than $\mathrm{Ag}^{+}$on the microbial community structure of activated sludge. Water Res 48:317-325

70. McGee C, Storey S, Clipson N, Doyle E (2017) Soil microbial community responses to contamination with silver, aluminium oxide and silicon dioxide nanoparticles. Ecotoxicology 26:449-458

71. Cho EC, Xie J, Wurm PA, Xia Y (2009) Understanding the role of surface charges in cellular adsorption versus internalization by selectively removing gold nanoparticles on the cell surface with a $\mid 2 /$ Kl etchant. Nano Lett 9:1080-1084

72. Villanueva A, Cañete M, Roca AG, Calero M, Veintemillas-Verdaguer S, Serna CJ, del Puerto MM, Miranda R (2009) The influence of surface functionalization on the enhanced internalization of magnetic nanoparticles in cancer cells. Nanotechnology 20:1-9

73. Wang D, Jaisi DP, Yan J, Jin Y, Zhou D (2015) Transport and retention of polyvinylpyrrolidone-coated silver nanoparticles in natural soils. Vadose Zone J 14:vzj2015.01.0007

74. Li X, Lenhart JJ, Walker HW (2010) Dissolution-accompanied aggregation kinetics of silver nanoparticles. Langmuir 26:16690-16698

75. Maillard J-Y, Hartemann P (2013) Silver as an antimicrobial: facts and gaps in knowledge. Crit Rev Microbiol 39:373-383

76. McShan D, Ray PC, Yu H (2014) Molecular toxicity mechanism of nanosilver. J Food Drug Anal 22:116-127

77. Schlich K, Klawonn T, Terytze K, Hund-Rinke K (2013) Hazard assessment of a silver nanoparticle in soil applied via sewage sludge. Environ Sci Eur 25:1-14

78. Yang Y, Wang J, Xiu Z, Alvarez PJ (2013) Impacts of silver nanoparticles on cellular and transcriptional activity of nitrogen-cycling bacteria. Environ Toxicol Chem 32:1488-1494

79. Choi O, Deng KK, Kim N-J, Ross L, Surampalli RY, Hu Z (2008) The inhibitory effects of silver nanoparticles, silver ions, and silver chloride colloids on microbial growth. Water Res 42:3066-3074

80. Liang Z, Das A, Hu Z (2010) Bacterial response to a shock load of nanosilver in an activated sludge treatment system. Water Res 44:5432-5438

81. Giles ME, Morley NJ, Baggs EM, Daniell TJ (2012) Soil nitrate reducing processes-drivers, mechanisms for spatial variation, and significance for nitrous oxide production. Front Microbiol 3:407-423 
82. Ji B, Yang K, Zhu L, Jiang Y, Wang H, Zhou J, Zhang H (2015) Aerobic denitrification: A review of important advances of the last 30 years. Biotechnol Bioprocess Eng 20:643-651

83. Tiedje JM (1988) Ecology of denitrification and dissimilatory nitrate reduction to ammonium. Biol Anaerob Microor 717:179-244

84. Asadishad B, Chahal S, Akbari A, Cianciarelli V, Azodi M, Ghoshal S, Tufenkji N (2018) Amendment of agricultural soil with metal nanoparticles: effects on soil enzyme activity and microbial community composition. Environ Sci Technol 52:1908-1918

85. Panáček $A$, Kvítek $L$, Smékalová $M$, Večeřová $R$, Kolář $M$, Röderová $M$, Dyčka F, Šebela M, Prucek R, Tomanec O (2018) Bacterial resistance to silver nanoparticles and how to overcome it. Nat Nanotechnol 13:65

86. Samarajeewa AD, Velicogna JR, Princz JI, Subasinghe RM, Scroggins RP, Beaudette LA (2017) Effect of silver nano-particles on soil microbial growth, activity and community diversity in a sandy loam soil. Environ Pollut 220:504-513

87. He S, Feng Y, Ni J, Sun Y, Xue L, Feng Y, Yu Y, Lin X, Yang L (2016) Different responses of soil microbial metabolic activity to silver and iron oxide nanoparticles. Chemosphere 147:195-202

88. Metreveli G, Frombold B, Seitz F, Grün A, Philippe A, Rosenfeldt RR, Bundschuh M, Schulz R, Manz W, Schaumann GE (2016) Impact of chemical composition of ecotoxicological test media on the stability and aggregation status of silver nanoparticles. Environ Sci Nano 3:418-433

89. Jacobson AR, McBride MB, Baveye P, Steenhuis TS (2005) Environmental factors determining the trace-level sorption of silver and thallium to soils. Sci Total Environ 345:191-205

90. Levard C, Hotze EM, Lowry GV, Brown GE Jr (2012) Environmental transformations of silver nanoparticles: impact on stability and toxicity. Environ Sci Technol 46:6900-6914

91. Tripathi DK, Tripathi A, Singh S, Singh Y, Vishwakarma K, Yadav G, Sharma S, Singh VK, Mishra RK, Upadhyay R (2017) Uptake, accumulation and toxicity of silver nanoparticle in autotrophic plants, and heterotrophic microbes: a concentric review. Front Microbiol 8:1-16

92. Jung WK, Koo HC, Kim KW, Shin S, Kim SH, Park YH (2008) Antibacterial activity and mechanism of action of the silver ion in Staphylococcus aureus and Escherichia coli. Appl Environ Microbiol 74:2171-2178

93. Nies DH (1999) Microbial heavy-metal resistance. Appl Microbiol Biotechnol 51:730-750

94. Keesstra SD, Bouma J, Wallinga J, Tittonell P, Smith P, Cerdà A, Montanarella L, Quinton JN, Pachepsky Y, van der Putten WH (2016) The significance of soils and soil science towards realization of the United nations sustainable development goals. Soil 2:111-128

95. Wu B, Wang Y, Lee $Y-H$, Horst A, Wang Z, Chen D-R, Sureshkumar R, Tang YJ (2010) Comparative eco-toxicities of nano-ZnO particles under aquatic and aerosol exposure modes. Environ Sci Technol 44:1484-1489

96. Sudheer Khan S, Bharath Kumar E, Mukherjee A, Chandrasekaran N (2011) Bacterial tolerance to silver nanoparticles (SNPs): aeromonas punctata isolated from sewage environment. J Basic Microbiol 51:183-190
97. Juan W, Kunhui S, Zhang L, Youbin S (2017) Effects of silver nanoparticles on soil microbial communities and bacterial nitrification in suburban vegetable soils. Pedosphere 27:482-490

98. Ma Y, Metch JW, Vejerano EP, Miller IJ, Leon EC, Marr LC, Vikesland PJ, Pruden A (2015) Microbial community response of nitrifying sequencing batch reactors to silver, zero-valent iron, titanium dioxide and cerium dioxide nanomaterials. Water Res 68:87-97

99. Cornelis G, Kirby JK, Beak D, Chittleborough D, McLaughlin MJ (2010) A method for determination of retention of silver and cerium oxide manufactured nanoparticles in soils. Environ Chem 7:298-308

100. Shoults-Wilson WA, Reinsch BC, Tsyusko OV, Bertsch PM, Lowry GV, Unrine JM (2011) Role of particle size and soil type in toxicity of silver nanoparticles to earthworms. Soil Sci Soc Am J 75:365-377

101. Postgate JR (1967) Viability measurements and the survival of microbes under minimum stress. Adv Microb Physiol 1:1-23

102. Cornelis G, DooletteMadeleine Thomas C, McLaughlin MJ, Kirby JK, Beak DG, Chittleborough D (2012) Retention and dissolution of engineered silver nanoparticles in natural soils. Soil Sci Soc Am J 76:891-902

103. Sagee O, Dror I, Berkowitz B (2012) Transport of silver nanoparticles (AgNPs) in soil. Chemosphere 88:670-675

104. Liu J, Hurt RH (2010) Ion release kinetics and particle persistence in aqueous nano-silver colloids. Environ Sci Technol 44:2169-2175

105. Marambio-Jones C, Hoek EM (2010) A review of the antibacterial effects of silver nanomaterials and potential implications for human health and the environment. J Nanopart Res 12:1531-1551

106. Verma A, Stellacci F (2010) Effect of surface properties on nanoparticlecell interactions. Small 6:12-21

107. Park E-J, Yi J, Kim Y, Choi K, Park K (2010) Silver nanoparticles induce cytotoxicity by a Trojan-horse type mechanism. Toxicol Vitro 24:872-878

108. Uwizeyimana H, Wang M, Chen W, Khan K (2017) The eco-toxic effects of pesticide and heavy metal mixtures towards earthworms in soil. 55:20-29

109. Stein LY, Arp DJ (1998) Loss of ammonia monooxygenase activity in Nitrosomonas europaea upon exposure to nitrite. Appl Environ Microbiol 64:4098-4102

110. Bollag J-M, Henninger NM (1978) Effects of nitrite toxicity on soil bacteria under aerobic and anaerobic conditions. Soil Biol Biochem 10:377-381

111. Das P, Barua S, Sarkar S, Chatterjee SK, Mukherjee S, Goswami L, Das S, Bhattacharya S, Karak N, Bhattacharya SS (2018) Mechanism of toxicity and transformation of silver nanoparticles: inclusive assessment in earthworm-microbe-soil-plant system. Geoderma 314:73-84

112. Cornelis G, Pang L, Doolette C, Kirby JK, McLaughlin MJ (2013) Transport of silver nanoparticles in saturated columns of natural soils. Sci Total Environ 463:120-130

113. Gunsolus IL, Mousavi MP, Hussein K, Bühlmann P, Haynes CL (2015) Effects of humic and fulvic acids on silver nanoparticle stability, dissolution, and toxicity. Environ Sci Technol 49:8078-8086

\section{Submit your manuscript to a SpringerOpen ${ }^{\circ}$ journal and benefit from:}

- Convenient online submission

- Rigorous peer review

- Open access: articles freely available online

- High visibility within the field

- Retaining the copyright to your article

Submit your next manuscript at springeropen.com 